IZA DP No. 7900

Empowering Women:

The Effect of Schooling on Young Women's

Knowledge and Use of Contraception

Mabel Andalón

Jenny Williams

Michael Grossman

January 2014 


\title{
Empowering Women: The Effect of Schooling on Young Women's Knowledge and Use of Contraception
}

\author{
Mabel Andalón \\ University of Melbourne \\ and IZA \\ Jenny Williams \\ University of Melbourne \\ and IZA \\ Michael Grossman \\ City University of New York Graduate Center, \\ NBER and IZA
}

\author{
Discussion Paper No. 7900 \\ January 2014
}

IZA

P.O. Box 7240

53072 Bonn

Germany

Phone: +49-228-3894-0

Fax: +49-228-3894-180

E-mail: iza@iza.org

Any opinions expressed here are those of the author(s) and not those of IZA. Research published in this series may include views on policy, but the institute itself takes no institutional policy positions. The IZA research network is committed to the IZA Guiding Principles of Research Integrity.

The Institute for the Study of Labor (IZA) in Bonn is a local and virtual international research center and a place of communication between science, politics and business. IZA is an independent nonprofit organization supported by Deutsche Post Foundation. The center is associated with the University of Bonn and offers a stimulating research environment through its international network, workshops and conferences, data service, project support, research visits and doctoral program. IZA engages in (i) original and internationally competitive research in all fields of labor economics, (ii) development of policy concepts, and (iii) dissemination of research results and concepts to the interested public.

IZA Discussion Papers often represent preliminary work and are circulated to encourage discussion. Citation of such a paper should account for its provisional character. A revised version may be available directly from the author. 


\section{ABSTRACT \\ Empowering Women: The Effect of Schooling on Young Women's Knowledge and Use of Contraception}

Large differences in fertility between women with high and low levels of education suggest that schooling may have a direct impact on knowledge and use of contraception. We investigate this issue using information on women in Mexico. In order to identify the causal effect of schooling, we exploit temporal and geographic variation in the number of lower secondary schools built following the extension of compulsory education in Mexico from 6th to 9th grade in 1993. We show that raising females' schooling beyond 6th grade increases their knowledge of contraception during their reproductive years and increases their propensity to use contraception at sexual debut. This indicates that the impact of schooling on women's wellbeing extends beyond improved labour market outcomes and includes greater autonomy over their fertility.

\section{NON-TECHNICAL SUMMARY}

Access to contraception is key to empowering women with autonomy over their own fertility. Using information on women in Mexico, we show that school completion beyond 6th grade increases women's knowledge of contraception and the propensity to use contraception at sexual debut. This indicates that the impact of schooling on women's wellbeing includes greater autonomy over their fertility.

JEL Classification: I10, I18, I25

Keywords: schooling, empowerment, contraception, knowledge, natural experiment, Mexico

Corresponding author:

Mabel Andalón

Department of Economics

Level 4, FBE Building 105

111 Barry Street

University of Melbourne

Melbourne, VIC 3010

Australia

E-mail: mandalon@unimelb.edu.au 


\section{Introduction}

Access to contraceptive methods is essential to securing the wellbeing and autonomy of women (World Health Organization, 2012). By decreasing exposure to AIDS, and to the complications of pregnancy and childbirth, the use of contraception has the potential to prevent more than one third of maternal mortality globally (United Nations, 2011). Contraception also enables women to plan their families, in terms of timing and spacing as well as the number of births. This ability to plan empowers women in spheres outside the home, for example, allowing them to participate in paid employment. Despite this, many women in the developing world do not have access to contraception. The United Nations estimates that around 222 million women in developing countries who wish to delay or stop childbearing are not using any method of contraception (Singh \& Darroch, 2012).

Contraception is widely recognised as a means to achieving the Millennium Development Goal of empowering women. As a consequence, there is considerable interest amongst policy makers in understanding the drivers of women's use of contraception (World Health Organization, 2011) 1 The available evidence suggests that the most important barrier to contraceptive use in developing nations is inaccessibility, principally due to a lack of knowledge about contraception (Bulatao, 1998). However, the large differences in fertility rates between more and less educated women within countries suggest that this lack of knowledge is more acute amongst those with little education (Skirbekk, 2008). This raises the question of whether schooling has a direct effect on women's knowledge and use of contraception, and hence autonomy over their fertility $\left.\right|^{2}$

The aim of this paper is to investigate whether schooling is causally related to knowledge and use of contraceptive methods in a developing country context, specifically Mexico in the 1990's. Economic theory suggest that schooling should increase knowledge and use of contraception. For example, schooling may improve women's ability to acquire and

\footnotetext{
${ }^{1}$ Contraception is also seen as instrumental for achieving the goals of improving maternal health and combating AIDS.

2 Rosenzweig \& Schultz (1989) and Michael (1973) provide evidence that schooling is associated with greater knowledge of contraceptive methods and a lower risk of conception, respectively, for the US.
} 
assimilate information about the benefits of family planning, and hence their use of contracption (Kenkel, 1991; Rosenzweig, 1995). Schooling can also lead women to demand fewer children and more contraception if it makes them more efficient producers of healthier (better quality) children (Becker, 1960; Becker \& Lewis, 1973; Becker, 1991; Willis, 1973) or more future oriented (Becker \& Mulligan, 1997; Perez-Arce, 2011). Finally, since schooling is in itself a form of empowerment (Duflo, 2012), it is likely to have long lasting effects on female autonomy by increasing the self-confidence that is necessary to negotiate and bargain with the male authority figures in their lives.

Despite the wide-spread interest in increasing female empowerment in developing countries, the drivers of women's autonomy with respect to family planning and contraception use have, for the most part, been overlooked in the economics literature. The vast majority of research in economics has examined the causes and consequences of female economic empowerment (Buvinić et al. 2013). This body of research has found that income earned by women, particularly outside their husband's farms, increases their autonomy in household decisions (Anderson \& Eswaran, 2009). There is also evidence that cash transfers disbursed to women whose families participate in conditional cash transfer (CCT) programs improve child inputs and households expenditures Attanasio \& Lechene, 2002, Gitter \& Barham, 2008; Rubalcava et al. 2009), but the evidence on whether this is a result of active female decision-making is mixed (Adato et al., 2000, Duflo et al., 2013, Handa et al., 2009). Much less is known about the drivers of female autonomy in the realm of contraception. Notable exceptions are de Brauw et al. (2013) who show that participation in a CCT program in Brazil increased exclusively female control over contraception decisions, and Mocan \& Cannonier (2012) and Dinçer et al. (2013) who find that schooling increases the propensity to use modern contraception in Sierra Leon and Turkey ${ }^{3}$ Our research adds to this small but emerging literature on female autonomy and the use of contraception in developing countries. In addition, we also make a contribution

\footnotetext{
$\sqrt[3]{\text { de Brauw et al. }}(2013)$ are, however, unable to determine whether the increase in female control translated into increased contraceptive use, nor could they isolate the effect of the cash transfer from that of the conditionalities of the program (e.g. health information sessions or schooling) on autonomy over contraception decisions.
} 
to the development literature investigating the impact of schooling on fertility related behaviours more broadly (Breierova \& Duflo, 2004; Lavy \& Zablotsky, 2011; Osili \& Long, 2008).

In this study, we examine the causal impact of schooling on women's knowledge of contraceptive methods during their reproductive years and their use of contraceptive methods at their sexual debut. These outcomes speak directly to the issue of women's autonomy with respect to family planning and fertility. For example, the decision to use contraception is manifest only if women are aware and informed about contraceptive methods. Finding that schooling increases knowledge about contraception would suggest that schooling contributes to the process of empowering women with the ability to obtain and utilize information for the purpose of making fertility related decisions. A women's sexual debut is a significant life event. Since contraceptive use depends on the interplay between the preferences of a woman and her partner, along with other social expectations and pressures, finding an effect of schooling on the use of contraception at sexual debut would be a clear indicator of female empowerment at an early age.

The empirical challenge in identifying the causal effect of schooling on these contraception related outcomes is accounting for the potential for common unobserved confounders that effect women's schooling and their contraceptive knowledge and use. For example, future orientation is likely to induce women to attend school for longer periods and to make greater efforts to learn about contraception through school based sex education classes or medical service providers. If this is the case, OLS estimates of schooling would lead to an overstatement of the true effect. On the other hand, precocious young women might be more successful at school and more likely to engage in risky sexual behavior, leading to OLS estimates that understate the effect of schooling.

In order to identify the causal effect of schooling on knowledge and use of contraception, we exploit plausibly exogenous changes in school attainment induced by Mexico's education reform. In the early 1990's, the Mexican Government embarked on an unprecedented program of reform that was designed to modernize its education sector. The 
education reform, a result of Mexico's National Agreement for the Modernization of Basic Education in 1992, consisted of two main components: 1) an increase in the level of compulsory provided education from primary school (6th grade) to lower secondary school (9th grade), and 2) a school building program that saw 6188 new public lower secondary schools built between 1993 and 1998. The school building occurred at different rates over the period from 1993 to 1998 across Mexico's thirty two states. This induced variation in exposure to the reform based on an individual's state of birth as well as their age when the reform was introduced. Thus, the education reform provides a natural experiment that generates plausibly exogenous variation in education that we use to identify the causal effect of education on contraceptive knowledge and use 4

Our results suggest that the returns to completing at least one grade of lower secondary education include an increase in knowledge and use of contraceptive methods during the first sexual encounter, but with considerable heterogeneity in effects. Our findings suggest that policy interventions to increase female schooling at the lower tail of the education distribution, particularly in rural areas, lead to greater female physical autonomy as measured by knowledge of contraceptive methods during women's reproductive years and use of contraceptive methods at sexual debut. Aside from the medical benefits of contraceptive use for women and their children, greater physical autonomy is likely to be conducive to greater female empowerment within and outside the household. This is of direct policy relevance for Mexico and for many other Latin American countries that reformed their public education systems at the lower secondary level during the 1990s.

The paper is structured as follows: Section 2 provides background information on education and fertility in Mexico. Section 3 describes the data used in our analysis and section 4 outlines our empirical model and identification strategy. Section 5 presents the empirical analysis of the effect of schooling on contraceptive knowledge. Section 6 reports an extensive series of sensitivity analyses and section 7 concludes.

\footnotetext{
${ }^{4}$ Our empirical strategy builds on the strand of literature that has attempted to estimate the causal effects of schooling on labour market outcomes (e.g. Duflo (2001)) and on non-market outcomes, which is summarized in detail by Grossman \& Kaestner (1997) and Grossman (2006).
} 


\section{Education and Fertility in Mexico}

Prior to 1992, primary education in Mexico (grades 1 through 6) was compulsory and nearly universal but lower secondary education (grades 7 through 9) was largely viewed as an optional continuation of primary studies (Levinson, 1999). In 1989, with the goal of expanding the "provision of lower secondary educational services" (Poder Ejecutivo Federal, 1999, p.41) the Mexican Government started an unprecedented educational modernization program that involved a number of administrative and curricular reforms. In 1992, administrative resources were decentralized from the Federal to State Governments. In July of 1993, the law was amended to require nine years of schooling, making lower secondary education a constitutional right for children that completed the 6th grade at the end of the school year 1992-1993.5

By making it a constitutional right, the Government was obliged to provide access to lower secondary education to any student graduating from primary school (Cuervo et al. 2009). To meet this obligation, a program to construct a large number of public lower secondary schools was undertaken 6 Between the school years of 1993-1994 and 1998-1999, 6159 new public lower secondary schools were constructed. This increased the number of schools per 1000 children aged 12 to 14 by 1.09, or around 30\%, over the period 1993-1998. The education reform succeeded in significantly increasing lower secondary enrollments. The percentage of children aged 12-14 who were enrolled in lower secondary schools had been at $69.1 \%$ in the ten years before the education reform began in 1993.7 By 1998, it had increased to $79.1 \%$

\footnotetext{
${ }^{5}$ The education system is composed of three levels: basic (includes pre-primary, primary and lowersecondary), upper-secondary education (high school) and tertiary education (technician, bachelor's degree and postgraduate studies).

${ }^{6}$ Tuition and books in public schools in Mexico are free of charge. However, students pay the costs of exam fees, transport and/or other living costs and schooling materials.

${ }^{7}$ Authors' calculations based on enrolment data from the Ministry of Education, obtained in August 2012 from http://www.snie.sep.gob.mx/estadisticas_education The number of children aged 12-14 in each year is from Consejo Nacional de Poblacin (CONAPO): http://www.conapo.gob.mx/

${ }^{8}$ It is worth noting that while the 1993 legislation made education through to the ninth grade a constitutional right and parents are responsible for ensuring that their children complete at least 9th grade, neither parents nor children are prosecuted if children leave school before completing 9th grade. It is still the case that less than $100 \%$ children complete 9 th grade. In 2010, just $21.3 \%$ of women aged 15 and older in 2010 had completed grade 9 INEGI (2012b).
} 
Two notable features of the school construction program are that (1) it was rolled out at different points in time across Mexico's 32 states, and (2) the number of the schools built differed from state to state. These features are demonstrated in Figure 1 which graphs the cumulative number of new public lower secondary schools opening per 1000 children aged 12-14 over the school years 1993-4 to 1998-9 for three of the richest and three of the poorest states in Mexico. Figure 1 shows that, for Mexico city (one of the richest states), the cumulative number of new schools opening rose from 0.01 per 1000 12-14 year olds in 1993-4 to 0.07 in 1998-9. In contrast, in Oaxaca (one of the poorest states), it rose from 0.42 new schools per $100012-14$ year olds to 2.03 over the same period. This variation provides the source of identification for the effect of schooling in the analysis that follows.

Coinciding with the introduction of the Modernization of Basic Education in the early 1990s (and the subsequent increase in lower secondary enrolments) has been a marked decline in the fertility rate of women in Mexico. The fertility rate fell from 3.5 children per woman in 1992 to 2.3 in 2009 (INEGI, 2012a). There are, however, significant differences in fertility by education level. For example, women with no education had 3.8 children on average in 2009 while women with lower secondary education had 1.6 children (INEGI, 2012a). Assuming that fertility control is achieved through the use of contraception, these statistics suggest that higher levels of education are associated with greater knowledge and use of contraception. In this research, we seek to determine whether this association is causal.

More specifically, this research seeks to investigate whether education leads to an increase in knowledge about contraception and to an increase in the use of contraceptives at a critical time in young women's sexual life. In the case of Mexico, school attendance at the lower secondary level should have a direct effect on contraceptive knowledge because sex education has been taught as part of the lower secondary school curriculum since the early 1970s $!^{9}$ Following the 1992 Education Modernization Program, classes on contraception were moved from the third to the second year of lower secondary schooling and were taught

http://www.ite.educacion.es/formacion/materiales/80/cd_1_2_3/cd2/paises/mexico/los_ materiales_educativos_en_mexico.pdf 
in greater depth. 10 Therefore children who completed lower secondary education before and after 1993 should have received sex education that included contraception, but those who attended after the 1993 school reform may have benefited from a more extensive treatment of contraception. 11

Aside from the information on contraception provided as part of their lower secondary education, all women of reproductive age, regardless of health insurance status, can obtain information about contraception at health clinics in Mexico through family planning programs (Juárez et al., 2010). The first family planning program in Mexico was introduced in 1974. The purpose of these programs was to disseminate information on contraception, and provide family planning services in health units in the public sector (Juárez et al. 2010). In 1994, with the publication of the Mexican Family Planning Norm, the principles, policies and strategies for the provision of family planning services became standardized. Under the Norm the promotion and dissemination of family planning services is done through mass media communication, social and community participation, group techniques, personal interviews, and home visits ${ }^{12}$ Information, guidance and counselling on family planning and use of contraceptive methods is offered to all women and men of reproductive age visiting health clinics (regardless of the purpose of the visit). The information and advice given is appropriate to the different stages of the person's reproductive life ${ }^{13}$ However, evidence suggests that adolescents are not familiar with the reproductive health services offered at clinics (Schiavon, 2008).

\footnotetext{
${ }^{10}$ Children who attended elementary education after 1993 were intended to benefit from basic sexual education (e.g. male and female reproductive systems, pregnancy, childbirth and post-partum) in grades 5 and 6, but the textbooks were not available until 1999 and 2000. (http://www.iea.gob.mx/webiea/ sistema_educativo/planes/plan_primaria.pdf). The amount of sex education received by students who attended elementary education up until 1998 did not change with the education reform.

${ }^{11}$ However, evidence indicating that elementary and secondary teachers had insufficient knowledge about contraception, and felt uncomfortable teaching materials on sex education (INEGI, 2002) may have impeded knowledge acquired at school.

${ }^{12}$ However, evidence suggests that there has not been a sound communication strategy to inform and raise awareness about sexual health as the topic of sexuality is discussed only sporadically in radio and television programs (Carballido, 2008).

${ }^{13}$ The 1994 Family Planning Norm covered the following methods: hormonal (oral, injectable and subdermal), intrauterine device, bilateral tubal occlusion, vasectomy, barrier methods and spermicides, natural methods (timing, rhythm or Ogino-Knaus, temperature, cervical mucus or billings and symptothermal). The Norm was updated in 2004 to include the emergency pill, female condom and diaphragm (as part of the barrier methods) and lactation amenorrhea.
} 
Note that the Family Planning Norm was implemented throughout the whole of Mexico in 1994, so it is unlikely to pose a threat to our identification strategy which exploits variation in the timing and intensity of the construction of public lower secondary schools across Mexico's states. Nonetheless, we carry out an extensive sensitivity analysis which examines this issue, along with several other potential threats to the identification and interpretation of our findings (including differential access to the internet, and religious schools). To preview the outcome of this analysis, we find a robustly significant causal impact of schooling on knowledge of contraceptive methods and the use of contraception at sexual debut, although our estimates may be viewed as providing a lower bound on the true effects.

\section{Data}

\subsection{The ENADID}

Our analysis draws on data from the Encuesta Nacional de la Dinámica Demográfica (ENADID). The ENADID is a household-based cross sectional survey of contraceptive practices, fertility history, and educational attainment of women aged 15 to 54 years in Mexico. We use the ENADID 2009, which was conducted by the national statistical agency, the Instituto Nacional de Estadística, Geografía e Informática (INEGI) and the National Population Council (CONAPO) 14 Over 100,000 women completed the ENADID survey in 2009. Our analysis is based on the 33,913 women who were aged 7 to 12 and 15 to 22 years when the education reform was launched in 1993 15 As discussed below, this sample includes women who were exposed to the eduction reform (and who form the treated group) and women who were not exposed to the reform (who form the control group). We limit our analysis to women because neither the ENADID nor any other Mexican survey that is representative at the national level ask men to report their educational attainment

\footnotetext{
${ }^{14}$ Although the survey was also conducted in 2006, we only use the 2009 wave because the ENADID 2006 does not contain information on state of birth, which is required in order to match individuals with the state level measure of school construction intensity at age 12 .

${ }^{15}$ The sample size is net of the 467 observations that had missing data on knowledge about contraceptive methods, use of birth control during first encounter or control variables.
} 
and contraceptive knowledge and practices.

The key outcomes of interest in this research are measures of knowledge and use of contraception. Knowledge about contraception at the time of the survey is measured by the number of methods that women report to knowing when asked: "Could you tell me which methods or means a couple can use to avoid or delay a pregnancy that you have heard about?" The 13 methods listed include: bilateral tubal occlusion, vasectomy, the pill, injections, implant, patch, intrauterine device, male condom, female female condom, foams, natural methods (calendar, rhythm and abstinence), withdrawal, and hormonal post coitus methods (emergency pill).

We measure women's use of contraception at sexual debut with an indicator constructed using responses to the question "In your first encounter, what contraceptive methods did you or your partner use?" The indicator is coded as one if the respondent reported using at least one of the enumerated methods, and is coded as zero if the respondent reported that they "did not use anything" 16 We note that although this information is reported retrospectively, one's sexual debut is typically a significant and memorable life event, and for this reason recall error is unlikely to pose a significant problem. However, to the extent that there is random misreporting (Cremin et al., 2009), the standard errors of the regression coefficients will increase.

We use information from the ENADID on the respondent's date and state of birth to link individuals to the state level measure of school construction intensity at age 12 , the state level measure of the number of health clinics at age 12 , and the following preprogram state characteristics: lower secondary school enrolment rate per child aged 12-14 in 1991, and the employment share in agriculture in 1990. The school construction data and the data on the number of lower secondary school enrollments is from the Ministry of Education (Sistema Nacional de Estadística Educativa, in Spanish). Data on the number of people employed in each employment sector in 1990 and on health clinics is from IN-

\footnotetext{
${ }^{16}$ Enumerated methods are: 1. Male vasectomy; 2. Intrauterine device, contraceptive coil; 3 Hormonal method (the pill, injections, subdermal implant, patch, emergency contraceptive); 4 Condom(s); 5 Other (spermicide, jellies or foam, rhythm, calendar, withdrawal); 6 didn't use anything.
} 
EGI website. 17 Age-specific historical population data was obtained from the National Population Council 18

\subsection{Defining the Treated and Control Groups}

Children enter lower secondary school, which begins at grade 7, at the age of 12 in Mexico. Therefore, women aged 7-12 when the school year commenced on the 1st of September 1993 were exposed to the education reform, and they constitute the treated group. The final year of lower secondary school in Mexico is grade 9, and students are typically 14 years of age at the start of this grade. Consequently, women who were 15 years and older when the 1993 school year started on September 1st are expected to have completed lower secondary school before the reform was introduced and are therefore not exposed to the education reform $\sqrt{19}$ For this reason, 15-22 years old form the control group for the analysis. A-priori, it is not clear whether those aged 13 and 14 years of age at the start of the 1993 school year belong to the treatment or control group as the education reform targeted those entering grade 7 who are typically 12 but made provisions to accommodate 13 and 14 year olds ${ }^{20}$ In order to minimize biases arising from misclassification of individuals as treated (or control), we omit observations on individuals aged 13 or 14 in 1993 from our primary analysis. We investigate the sensitivity of our results to excluding these observations in section 621

\subsection{Summary Statistics}

Means and standard deviations for the outcomes of interest and control variables by treatment status are reported in Table 1. Statistically significant differences in means between treatment and control groups are indicated by asterisks in the final column of the table.

\footnotetext{
${ }^{17}$ http://www.inegi.org.mx/est/contenidos/proyectos/cubos/ and http://www3.inegi.org.mx/ sistemas/mexicocifras/default

${ }^{10}$ http://www. conapo.gob.mx/

${ }^{19}$ This is not true for individuals who repeat grades or who had delayed school entry.

${ }^{20}$ Those aged 13 and 14 in 1993 were allowed to continue their eduction, or return to school if they had left school after completing primary school.

${ }^{21}$ We also omit women who are still attending school when interviewed in 2009 to ensure that individuals in both the treated and control groups have completed their education when asked about their contraceptive knowledge and use.
} 
As can be seen from the table, women in the treated group complete 10.37 grades of school on average compared to 9.56 for women in the control group, and this difference is statistically significant. Women in the treated group are also more likely to have used birth control during their first sexual encounter (20.5\% in the treated group versus $14.7 \%$ in the control group). However, women in the control group are more knowledgable about birth control methods, reporting to know 10.63 methods on average compared with 10.55 methods known by members of the treated group. This is likely to be attributable to the fact that women in the treated and control groups are at different stages of their reproductive life. Note, for example, that women in the treated group are much younger (average age of 25.3 years compared to 34.3 years in the control group), less likely to have started their sexual life ( $84 \%$ have had sex compared to $95 \%$ in the control group), more likely to be single (33.2\% compared to $14 \%$ in the control group), and have fewer children (1.2 on average compared to 2.3 children for women in the control group). In the analysis that follows, we account for these differences as well as the potential endogeneity of education in our investigation of the causal effect of schooling on knowledge and use of contraception.

\subsection{Evidence of the Impact of the Education Reform}

In order for the education reform to serve as an instrument for schooling, and hence permit the identification of the causal effect of schooling on contraceptive knowledge and use, it must be the case that the reform impacted schooling outcomes. Evidence of the impact of the reform on schooling has been found by Andalón (2010) when looking at its effect on smoking behaviors. We investigated whether this is the case in our data by estimating the following linear probability model for the number of grades of school completed:

$$
S_{i a s m}=\alpha_{0}+\alpha_{1} T_{a} P_{a s}+\alpha_{2} T_{a} X_{s}^{\prime}+\sum_{a=7}^{21} \alpha_{3 a} C_{a}+\sum_{s=2}^{32} \alpha_{4 s} K_{s}+\alpha_{5} X_{i}^{\prime}+\varepsilon_{i a s m}
$$

where $S_{\text {iasm }}$ is a binary indicator equal to one if woman $i$ in birth cohort $a$ and birth state $s$ completed at least grade $m$, and the model was estimated $m$ times $\{\mathrm{m}=1,2, \ldots 18\}$. The variable measuring the education reform $T_{a} P_{a s}$, is the product of the indicator for 
belonging to a birth cohort in the treated group $\left(T_{a}=1\right.$ if age in 1993 is $\left.7-12\right)$ and the intensity of exposure to the public school building program faced by a woman in birth cohort $a$ born in region $s, P_{a s}$. The intensity of exposure to the public school building program is defined as the cumulative number of new government lower secondary schools per 1000 children aged 12-14 that were available to cohort $a$ with region of birth $s$ at age 12. The measure of the education reform reflects the fact that, for women in the treated group, the greater the number of public schools constructed in her state of birth before she started lower secondary education (per 1000 children aged 12-14), the more likely she is to have attended lower secondary school. To account for the fact that the government school building program was rolled out in a compensatory way, we include interactions between the indicator for treatment $T_{a}$ and a vector of state-level pre-program characteristics $X_{s}$ which includes i) the enrollment rate in 1991, and ii) the share of people employed in the agricultural sector in 1990. We account for cohort of birth and region of birth specific factors by including cohort fixed effects, $C_{a}$ and state-of-birth fixed effects, $K_{s} . X_{i}$ is a vector of individual characteristics that includes indicators for indigenous condition (5\% of the sample) and rural residence ( $20 \%$ of the sample) and $\varepsilon_{\text {iasm }}$ is the error term ${ }^{22}$

The solid line in Figure 2 plots the point estimates of the coefficient on the schooling reform variable resulting from these $m$ regressions, one for each schooling grade. The dashed lines provide the corresponding $95 \%$ confidence intervals. The figure shows that the education reform had a positive and significant effect on the probability of completing at least grades 7 to 9 with the biggest effect on the probability of completing at least grade 7 and the smallest (significant) effect on the probability of completing at least grade 9 . Given that the education reform is found to affect the probability of completing grades 7 and beyond, but not the likelihood of completing elementary education, and that formal sex education is taught as part of the lower secondary curriculum (see section 2), we use as our measure of schooling a binary indicator for completing at least one grade of lower secondary education.

\footnotetext{
${ }^{22}$ It would be interesting to test the role of religion on knowledge and use of contraceptive methods, but religious beliefs are not asked about in the ENADID.
} 


\section{Empirical Approach}

We seek to understand the impact of schooling on women's knowledge and use of contraceptive methods. As a starting point, we posit the following model for the contraceptive outcome of interest:

$$
Y_{i a s}=\beta_{0}+\beta_{1} S_{i a s}+\beta_{2} T_{a} X_{s}^{\prime}+\sum_{a=7}^{21} \beta_{3 a} C_{a}+\sum_{s=2}^{32} \beta_{4 s} K_{s}+\beta_{5} X_{i}^{\prime}+u_{i a s}
$$

where $Y_{\text {ias }}$ is defined as either the number of methods of contraception known at the time of survey by woman $i$ in birth cohort $a$ and birth state $s$, or as an indicator for use of contraception during her first sexual encounter. $S_{i a s}$ is an indicator equal to one if the woman completed at least one grade of lower secondary school and zero otherwise. We include interactions between the indicator for treatment $T_{a}$ and a vector of pre-program state specific characteristics $X_{s}$, cohort fixed effects $C_{a}$, state-of-birth fixed effects $K_{s}$, and a vector of individual characteristics, $X_{i}$. Our primary objective is to obtain a reliable

estimate of the coefficient on the indicator for attending lower secondary school, $\beta_{1}$. The issue in doing so is that unobserved factors that influence a woman's knowledge about contraceptive methods or her use of contraception during her first sexual encounter, such as precociousness, may also determine whether she attended lower secondary school. For this reason, we follow a two-stage least squares (TSLS) approach.

The first stage model for attending lower secondary school is given by:

$$
S_{i a s}=\alpha_{0}+\alpha_{1} T_{a} P_{a s}+\alpha_{2} T_{a} X_{s}^{\prime}+\sum_{a=7}^{21} \alpha_{3 a} C_{a}+\sum_{s=2}^{32} \alpha_{4 s} K_{s}+\alpha_{5} X_{i}^{\prime}+\varepsilon_{i a s} .
$$

This is identical to the linear probability model given by equation (1) used to investigate the impact of the schooling reform in Section 3.4 when $m=7$. That is, the outcome of interest in equation (3) is the probability of completing at least 7 th grade. The key variable of interest in this first stage regression is $T_{a} P_{a s}$, which is the product of the indicator for belonging to a birth cohort in the treatment group $\left(T_{a}=1\right.$ if age in 1993 is $\left.7-12\right)$ and the intensity of exposure to the public school building program faced by a woman 
in birth cohort $a$ born in region $s, P_{a s}$. This variable serves as the instrument which identifies the impact of schooling in the two stage least squares (TSLS) models for contraception knowledge and use ${ }^{23}$ Specifically, the coefficient on schooling in the equations for knowledge about and use of contraception is identified by differences in the availability of schools among different cohorts of women who were born in the same state. Our identifying assumption is that, having controlled for region specific time invariant effects and birth cohort specific effects, differences in the availability of schools are uncorrelated with unobserved determinants of contraceptive knowledge and contraceptive use at sexual debut 24

\section{Empirical Results}

\subsection{The Effect of Educational Reform on Schooling}

Estimates of the linear probability model for completing at least one grade of lower secondary school are reported in Table 2 . Column 1 reports our baseline specification, while columns $2-5$ report specifications which attempt to account for life-cycle factors related to fertility decisions and hence the demand for knowledge about and use of contraception. Standard errors clustered at the state level are reported in parentheses 25 Estimates of the

\footnotetext{
${ }^{23}$ As discussed above, the reform has not in fact lead to $100 \%$ of children completing 9 th grade. While this is most likely due to voluntary drop out (neither parents nor children are prosecuted for children failing to complete lower secondary school), we cannot rule out the possibility that, despite the sizable school construction program, capacity constraints lead some children to drop out before completing lower secondary education. This highlights the importance of accounting for the intensity of the school building program in the year in which each treatment cohort enters lower secondary education in addition to treatment status in using the school reform to identify the impact of education in the analysis that follows.

${ }^{24}$ Noting that the inputs into the production of health can be affected by both schooling and knowledge, previous work has attempted to separate the impact of schooling and knowledge on the consumption of cigarettes, alcohol and exercise (Kenkel, 1991). We do not have data on contraceptive knowledge at sexual debut, so the contraceptive use equation is estimated with contraceptive knowledge omitted as an explanatory variable. Under our identifying assumption, contraceptive knowledge can be excluded from the regression of contraceptive use because the school construction affects contraceptive knowledge only through its effect on school attainment. The coefficient of schooling on contraceptive use captures the total effect of schooling.

${ }^{25}$ Bertrand et al. (2004) and Angrist \& Pischke (2009) argue that obtaining consistent estimates of clustered standard errors requires between 42 and 50 clusters. However, Bertrand and her colleagues and Cameron et al. (2008) show that the rate of rejecting the null hypothesis when it is true is larger when there are 50 clusters than when there are 20, thus suggesting that 20 clusters are sufficient.We have 32 clusters.
} 
cohort and state of birth fixed effects (not reported) are available upon request. The key parameter of interest in this equation is the coefficient on the education reform variable, measured by the interaction between the cumulative number of new schools built and the indicator for treatment. In this analysis, the treated group is composed of women who were 7 to 12 in 1993 and the control group is composed of women who were 15 to 22 in 1993.

As shown in column 1 of Table 2, the education reform variable is associated with a statistically significant increase in schooling. Evaluated at the sample mean of 0.72 new public schools per 1000 children aged 12-14, the point estimate of 0.034 implies that the reform increased the probability of completing 7 or more grades of school by 2.45 percentage points. This compares to the sample average of 74.11 percent. The F-statistic on the school reform variable is 13.23 , exceeding the critical value of 10 that is used to assess whether instruments are weak (Stock et al., 2002). Looking across the top panel of the table, it is clear that the effect of the reform on a woman attending lower secondary school is robust to accounting for (potentially endogenous) life-cycle factors related to fertility and contraception (ever having sex, marital status, and the number of children).

\subsection{Effect of Schooling on Contraceptive Knowledge and Use}

In Tables 3 and 4 we report OLS and TSLS estimates of our model for the impact of schooling on the number of contraceptive methods known and use of contraception during the first sexual encounter, respectively. The upper panel of each table reports OLS coefficient estimates and their standard errors (in parentheses) while the lower panel reports TSLS coefficient estimates and their standard errors. All standard errors are clustered at the state level.

Beginning with Table 3 , the first column reports estimation results from the baseline specification that includes the controls listed in equation (2). The specifications in columns

$2-5$ of Table 3 account for milestones in women's reproductive lives that may impact on their post schooling acquisition of knowledge about contraception. Column 2 adds to 
the baseline specification an indicator for ever having sex, column 3 adds to the baseline specification indicators for married and widowed/divorced (omitted category is single), while column 4 augments the baseline specification with the number of (live) children the respondent has at the time of survey. Column 5 adds the full set of variables capturing reproductive milestones to the baseline specification.

Both the OLS and the TSLS estimates of the effect of completing at least one grade of lower secondary school from the baseline specification reported in column 1 of Table 3 are positive and statistically significant. The OLS point estimate implies that attaining education beyond elementary schooling increases a woman's knowledge of contraception by 2.1 methods whereas the TSLS estimate indicates an increase of 4.1 methods. This difference suggests a negative correlation between unobservables impacting on both schooling and contraceptive knowledge, as may occur if precocious women are more likely to continue studying but less likely to learn about contraceptive methods. Alternatively, the larger TSLS estimate may be evidence that the marginal benefit of schooling for the subpopulation that was affected by the education reform is higher than the effect for the average person. However, the Hausman test finds that the difference between the OLS and TSLS estimates is not statistically significant. It is important to note that the failure to find evidence of a statistical difference between the OLS and TSLS estimates is unlikely to be attributable to having a weak instrument. The $F$ statistic for the instrument in the first stage ranges from 12.11 to 13.23 across the five specifications, comfortably exceeding the rule of thumb value of 10 typically used (Stock et al., 2002). In terms of the magnitude of the estimated effect relative to the sample average, we find a $20 \%$ increase in the known methods of contraception amongst those with at least one grade of lower secondary education compared with those whose highest level of education is primary school.

The specifications in columns $2-5$ of Table 3 account for milestones in women's reproductive lives that may impact on their post schooling acquisition of knowledge about contraception. The results reported in columns 2 and 3 of Table 3 show that women who are sexually active and are married or divorced know more contraceptive methods than 
women who are not sexually active and are single. In contrast, women with more children (column 4) know fewer birth control methods. The inclusion of the full set of variables representing reproductive milestones, reported in column 5 , suggests that knowledge about contraceptives increases when women become sexually active. However, the inclusion of theses variables either separately (columns 2 to 4 ) or together (column 5) does not alter the magnitude of the schooling coefficient, confirming that completing at least one grade of lower secondary school increases the number of contraceptive methods a women knows. The Hausman test finds that the difference between the OLS and TSLS estimates is not statistically significant in columns $2-5$ of Table 3 . In appendix Table A.1 we show that schooling lead to greater knowledge of both very effective and less effective methods. ${ }^{26}$

Table 4 examines whether schooling impacts the likelihood of a woman using contraception during her first sexual encounter. As with Table 3, column 1 of Table 4 reports results from the baseline specification that includes the controls listed in equation (2). The specifications in columns 2 and 3 attempt to account for the fact that not all women in the sample report having had sex. To do so, the specification in column 2 adds to the baseline specification an indicator for whether the individual has ever had sex, while column 3 reports estimates based on the sub-sample of women who have had sex.

The results in Table 4 show that both OLS and TSLS produce positive and statistically significant estimates of the effect of education beyond elementary school on the probability that women use contraception at their sexual debut. ${ }^{27}$ The OLS point estimate indicates that the probability that a woman uses contraception during her first sexual encounter is 11 percentage points higher if she has completed at least one grade of lower secondary education. While the IV point estimate is around four times the size of the OLS estimate,

\footnotetext{
${ }^{26}$ The effectiveness of the methods was based on their failure rate, which is defined as the probability of unintended pregnancy within the first year of typical use. Very effective methods are those with failure rates of $10 \%$ or less and less effective methods are those with failure rates ranging from $12 \%$ to $28 \%$. The information on failure rates comes from the CDC (http://www.cdc.gov/ reproductivehealth/UnintendedPregnancy/Contraception.htm) and the emergency contraception website (http://ec.princeton.edu/questions/eceffect.html), which relies heavily on (World Health Organization and Johns Hopkins Bloomberg School of Public Health, 2011) and (Trussell, 2011). The findings are robust to the inclusion of the full set of variables representing reproductive milestones and an alternative definition of effectiveness based on a threshold of $5 \%$ failure rate.

27 The second stage results come from a linear probability model, but probit models (available upon request) produce very similar results.
} 
the Hausman test fails to find any significant difference between them ${ }^{28}$ The magnitude of the estimated effect of education beyond primary school is substantial. Given that only $17 \%$ of women in the sample use contraception at their sexual debut, the estimated 11 percentage point increase due to having more than a primary school education represents a $65 \%$ increase in the probability of contraception use at sexual debut. In columns 2 and 3 we investigate whether the potential for selection into ever having sex is impacting on our findings by adding an indicator for eve having sex, and dropping from the estimation sample those who have never had sex, respectively. As can be seen from the table, the point estimates in columns 2 and 3 are not significantly different from those in column 1 , suggesting that selection is not an issue in these data. This is not surprising given that more than $90 \%$ of the women in our sample report having had sex at least once in their life.

We provide some insight into why the school construction program was effective at increasing women's knowledge and use of contraception at sexual debut by examining sub-populations. Specifically, we repeat our analysis on the sample of non-indigenous women, the sample of women living in urban locations and the sample of women living in rural locations. These results are reported in Table 5. Note that column 1 of Table 5 repeats the basic specification for the full sample. All specifications include the controls listed in equation (2). Panel A reports first stage results, Panel B reports OLS and TSLS results for the outcome "number of contraceptive methods known", while Panel C reports OLS and TSLS results for the outcome "contraceptive use at sexual debut". Beginning with the first stage estimates, a comparison of columns 1 and 2 reveals that the point estimate for the non-indigenous sample is smaller than that for the full sample, suggesting that the effect of the education reform on the probability of having completed at least one grade of lower secondary school is larger among indigenous women. The estimates in columns 3 and 4 show that the effect of the education reform in rural areas is close to three times the effect in urban areas. As urban areas are more densely populated than rural

\footnotetext{
${ }^{28}$ As discussed above, the Hausman test finding is unlikely to be the result of using a weak instrument since the $F$ statistic on the instrument in the first stage is above 10 (at least in columns 1 and 2).
} 
areas, we hypothesize that the main effect of building schools in urban areas is to reduce overcrowding in schools. In rural areas, each new school would be expected to signicantly reduce the distance to school. If this is the case, our findings suggest that an important avenue through which the education reform increased lower secondary schooling was by improving physical access in rural locations. Specifically, the school building program reduced the distance a child in a rural location must travel to attend school 29

Panels B and C in Table 5 report OLS and TSLS estimates of the effect of completing at least one grade of lower secondary schooling on knowledge and use of contraception, respectively, for the non-indigenous, urban and rural sub-samples as well as the full sample. For both outcomes, the OLS estimates suggest that the magnitude of the effect of lower secondary schooling is smaller for the rural sample compared to the urban sample, whereas the magnitude of the schooling effect for the urban and non-indigenous samples are similar to the magnitude of the effect for the full sample. The TSLS estimates, however, indicate that while the impact of at least one year of lower secondary school is similar for the full and non-indigenous sample for each outcome, the effects are larger for the rural sample and statistically insignificant for the urban sample.

These results suggest that women in rural areas (where the reform had the largest impact on schooling) gained the most in terms of knowledge and use of contraception. We note, however, that the TSLS results should be interpreted with caution because the first stage F-statistics for the sub-samples are smaller than 10, although they exceed the value of 5, which Cameron \& Trivedi (2005) propose as a less strict rule of thumb.

\section{Robustness Checks}

\subsection{First Stage}

Our identification strategy is based on the assumption that differences in exposure to the public lower secondary school construction program associated with the educational reform

\footnotetext{
${ }^{29}$ Note that, since rural to urban migration is common in Mexico, the estimated effects based on the area of residence in 2009 rather than area of birth, which is unavailable, might be underestimating the effect in rural areas and overestimating the effect in urban areas.
} 
produced exogenous variation in the probability of completing at least one grade of lower secondary school. Therefore, distinguishing who is affected by the educational reform and who is not is key to our identification strategy. In order to investigate the validity of our approach, we examine the sensitivity of our fist stage estimates to (1) the potential for contamination of the control group due to late entry to school or grade repetition, and (2) the exclusion of observations on those aged 13 or 14 in 1993 . We conduct two other sensitivity tests to examine the validity of our instrument. The first considers private lower secondary school openings as an alternative instrument. The second investigates whether changes in school inputs rather than changes in access (via reduced distance) lead to an increase in educational attainment. The results using the baseline specification are reported in Table 6. Although not reported in the table, we note that our findings from these sensitivity analyses are robust to the the inclusion of the life-cycle milestones.

The youngest cohort assumed to be unaffected by the school reform is the cohort aged 15 on September 1st 1993. However, this cohort may be impacted if there are over age enrolments due to delayed entry into school or grade repetition. If this is the case, then the control group will include treated individuals, resulting in an under-estimate of the effect of the education reform on completing at least one grade of lower secondary school. We investigate this issue in column 1 of Table 6 by examining the sensitivity of our first stage estimates to excluding from the sample the cohort aged 15 in 1993. The resulting estimated effect of the reform is smaller than its counterpart reported in column 1 in Table 2. This suggests that the reform did not raise the probability of women who were 15 in 1993 completing at least one year of lower secondary school, confirming that they belong in the control group.

We next examine the decision to exclude cohorts aged 13 and 14 in 1993 from our sample. This decision was prompted by the fact that, although the reform targeted cohorts aged 12 and younger in 1993, provisions were made to accommodate 13 and 14 year olds who wished to continue, or return to, lower secondary school. This created some ambiguity as to whether these cohorts belonged to the treated or control group. We investigate this 
issue in column 2 of Table 6, in which we replicate the specification given in column 1 of Table 2, redefining the treated group to be the cohorts aged 13 and 14 in 1993 while retaining as the control group those aged 15 and older in 1993. The resulting point estimates of the coefficient on the reform variable are found to be statistically insignificant, suggesting that the education reform had no significantly different impact on the cohort of women who were 13 and 14 in 1993, as compared to those who were 15 to 22 . This supports the exclusion of these cohorts from the treatment group 30

Column 3 in Table 6 shows an alternative specification of our first stage equation (2) in which the indicator of treatment status is interacted with the cumulative number of new private lower secondary schools in the woman's state of birth at age 12. Given that the public school construction program has been shown to have its largest effect on the lower secondary school attendance of the most disadvantaged women, we would expect very little effect of private school openings. Finding a larger effect for private schools than for public schools would cast doubt on the validity of our instrument. As can be seen in column 3 of Table 6 the estimated coefficients on the interaction between treatment and private school construction is negative and statistically insignificant. This provides some confidence that the instrument used in our analysis is valid.

An important consideration when examining the impact of an intervention as extensive as Mexico's school construction program is whether it impacted the quality of lower secondary education. We investigate this issue using the pupil-teacher ratio as a measure of quality. The national pupil-teacher ratio was 17.9 in $1990,17.7$ when the school construction program began in 1993 and 17.3 when it ended in 1998. We therefore consider whether we are incorrectly attributing improved school attainment solely to the increase in the quantity of school when the effect may in part be attributable to the improved quality of schools, as measured by the pupil-teacher ratio. To do so, we add to our baseline specification an indicator for treatment status interacted with the pupil-teacher ratio in the women's state of birth in 1990. The results from this specification, reported in column

\footnotetext{
${ }^{30}$ We also examined the outcomes of interest for these women and the reform was not found to affect contraceptive knowledge or use of birth control during sexual debut.
} 
4 of Table 6 , show that the pupil-teacher ratio does not significantly affect women's completion of at least one grade of lower secondary education. More importantly, the effect of the education reform on schooling is robust to the inclusion of the pupil-teacher ratio. These results suggest that increases in school attainment are likely to have resulted from improving access to education (via reduced distance to school), rather than changes in the quality of education 31

\subsection{Second Stage}

Our identification strategy for estimating the effects of schooling on contraceptive knowledge and use is based on the assumption that the educational reform is uncorrelated with other unobserved factors that affect women's knowledge and use of contraception. One possible threat to this assumption is the introduction of the 1994 Mexican Family Planning Norm, which standardized the type of information offered at health clinics throughout the country from 1994. For the Norm to pose a threat to the validity of using the educational reform as an instrument, it would need to impact on treatment and control groups differentially across states of Mexico and over time, since the school building program varied across states and time over the period 1993-1998. While this is unlikely to be the case because Family Planning Norms are national programs, we investigate this issue in two ways. First, we examine whether the information provided through the Family Planning Norm of 1994 had differential effects on treated and control groups. Second, we attempt to directly control for the potential for a differential spread of birth control knowledge via the Norm across states and over cohorts. These results are reported in Table 7.

Our treated and control groups may have differentially benefited from the Family Planning Norm of 1994 because the two groups were at different stages in their reproductive lives when the Norm was introduced. In our sample, women start having sex at the age of 19, on average. As our control group is comprised of women aged 16-23 in 1994 when the Norm was introduced, it is likely that many would have started their sexual

\footnotetext{
${ }^{31}$ The same conclusion is reached if we use a measure of class size in the women's state of birth in 1990 instead of pupil to teacher ratio. The average class size was 33 in 1990, 32 in 1993 and 30 in 1998.
} 
life before the Norm's introduction. Assuming that women typically seek out information about contraception and acquire contraceptives around the time they start having sex, the sexually active women in the control would have benefited less from the Family Planning Norm of 1994 than those who were not sexually active. Simply put they would already have discovered the information promoted in the educational campaigns and offered at the health clinics for themselves. In contrast, cohorts in the treated group were 8 to 13 when the 1994 Family Planning Norm was introduced and unlikely to have had sex. Therefore, all in the treated group will have benefited from the standardization of information offered at health clinics but not all in the control group. If this is the case, we would expect a downward bias in the estimated effect of schooling on knowledge about contraception.

In order to investigate the degree to which this is a problem, we repeat our estimations removing from the sample observations for women who were 19 to 23 in 1994 since, on average, women in the sample have their sexual debut at 19 years of age. In doing so, we create a sample in which all individuals were exposed to the same information at health clinics at the start of their reproductive life. This in turn ensures that the only difference between treatment and control groups is the education reform. The results from this sensitivity analysis when the outcome is the number of contraceptive methods known and use of contraception at sexual debut are reported in columns 1 and 3 of Table 7 respectively. A comparison of results for the number of contraceptive methods known in column 1 of Table 7 and column 1 of Table 3 , and use of contraception in column 3 of Table 7 and column 1 of Table 4 show that when we omit observations on individuals who may not have benefitted from educational campaigns, the estimated effect of schooling on knowledge and use of contraception increases, although the difference between the estimates is not large 32

Next, we attempt to directly control for the potential for a differential spread of birth control knowledge via the Norm across states and over cohorts. To do this, we add to our

\footnotetext{
${ }^{32}$ This result is comparable to what has been found in Uganda where, for individuals who started their sexual life after the start of an information campaign that aims at preventing the HIV/AIDS epidemic, higher levels of education were found to be associated with a lower risk of being HIV positive (de Walque, 2007).
} 
baseline specification the per capita number of health clinics in each state at the time the respondent was 12 years of age. If the spread of information was quicker in states with higher intensities of school construction, accounting for health clinics would yield smaller effects of schooling on contraceptive knowledge and use at sexual debut. As shown in columns 2 and 4 of Table 7, the OLS results indicate that the effect of completing at least one year of lower secondary school on contraceptive knowledge and use is not sensitive to accounting for the number of health clinics. Overall, the results provide no evidence that a differential spread of information via the Norm explains the impact of completing at least one grade of lower secondary school on either contraceptive knowledge or the use of contraception during the first sexual encounter.

Another source of information about contraceptives is the internet. Internet use in Mexico began in 1997. The population with access to internet grew from less than $0.5 \%$ during the nineties (Telmex, 1999) to $40 \%$ in 2012 33 According to INEGI, $76 \%$ of the Mexicans navigating cyberspace are under the age of 35 suggesting that younger women who were affected by the education reform have more access to the information available on the internet than older women who were not affected by the reform. This would pose a problem to our identification strategy if internet access grew faster in states with a higher intensity of school construction (poor states). However, around $36 \%$ of the individuals in the richest Mexican states, such as Mexico City and Nuevo León had internet access in 2010, compared with $10 \%$ in the poorest states like Chiapas and Oaxaca. These data suggest that internet adoption was higher in richer states (where fewer schools were built) than in poorer states (where more schools were built and school attainment grew faster). Therefore, our estimates should be considered lower bounds for the effect of educational attainment on contraceptive knowledge and use.

A final potential source of confounding we investigate is differential information that may impact on knowledge and use of contraception resulting from attending a religious school. For example, the content of formal sex education may differ systematically between

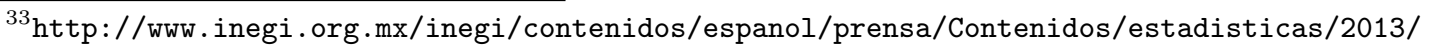
internet0.pdf
} 
religious, predominantly catholic schools, and other schools. This may be relevant since, while the Mexican Constitution of 1917 prohibited the Catholic Church from the delivery of education, a change in legislation in 1992 allows religious associations to establish private schools. In principle, however, sex education at religious and non-religious schools should not differ because the legislation requires religious schools to adhere to the same education standards, guidelines and curriculum as public schools, defined by the Ministry of Public Education. In practice, however, adherence to the sex education curriculum may be difficult to enforce. This would pose a problem for our identification strategy if students attending religious schools received less information in states with a low intensity of school construction. However, low intensity school construction states tend to be the wealthier, more socially progressive states. This suggests that if religious schools fail to adhere to the sex education curriculum, our estimates are likely to understate the effect of education on knowledge and use of contraception.

\section{Conclusion}

Previous research on empowerment in developing countries has focussed on the causes and consequences of economic empowerment of women. In this research, we consider a more fundamental empowerment issue, that of women's ability to control their own fertility. In particular, we investigate whether education empowers young women with the knowledge, or the ability to access knowledge about contraceptive methods and to use contraception at the important life transition of their sexual debut.

In order to disentangle the causal effect of education from unobserved confounders that may also determine a young women's knowledge and use of contraception, we exploit plausibly exogenous variation in schooling induced by Mexico's 1993 education reform. Our findings show that the education reform increased the proportion of women who completed at least one grade of lower secondary school by 2.45 percentage points. We also found evidence suggesting that the effect of the reform was driven by a reduction in distance to public schools in rural areas. In terms of knowledge and use of contraception, 
our findings suggest that increased schooling has lead Mexican women to have greater autonomy over their fertility decisions. Relative to women who finish elementary school or less, women who complete at least one grade of lower secondary school know 2.1 more birth control methods. This represents a $20 \%$ increase in known methods of contraception amongst those with at least one grade of lower secondary education. We also find that completing at least one grade of lower secondary school increases the likelihood that a young women uses contraception at her sexual debut by around 11 percentage points, or $65 \%$. These results are of direct policy relevance for Mexico and many other Latin American countries that reformed their public education systems during the 1990s to increase lower secondary attainment using a mix of policies.

Given the institutional context of our study, attending lower secondary school in Mexico could have increased women's knowledge about methods of contraception either through school based formal sex education or by increasing their ability to acquire this information from other sources such as the internet. Most likely, the effect of schooling on women's decision to use contraception during the first sexual encounter was driven by increased awareness about different contraceptive options and their benefits. Another possibility is that more educated women use contraception at sexual debut because they choose more educated partners who strongly prefer to use contraception (Breierova \& Duflo, 2004). Finally, it is possible that schooling affected female autonomy by making women more future oriented. Unfortunately, we lack the data required to explore the relative contribution of these potential avenues through which schooling may affect contraceptive knowledge and use. This is clearly an important area for future research.

Fertility control has been found to improve maternal and child health (World Health Organization, 2011). We provide evidence that knowledge and use of contraception is increased by raising women's education. Furthermore, greater physical and household empowerment are likely to promote further the equality between men and women by increasing female empowerment in the public sphere. All in all, this suggests that investing in female education is a crucial strategy to increasing women's capacity to become their 
own agents, which is a desirable goal in and of itself, and is also instrumental in improving the living standards of current and future generations in developing countries. 


\section{References}

Adato, M, de la Briere, B., Mindek, D., \& Quisumbing, A. 2000. Final report: The impact of PROGRESA on womens status and intra household relations. Tech. rept. International Food Policy Research Institute, Food Consumption and Nutrition Division, Washington, DC.

Andalón, Mabel. 2010. The Effect Of Public Policies On Smoking Behaviors: Perspectives From A Developing Country. Ph.D. thesis, Cornell University, Ithaca, NY.

Anderson, Siwan, \& Eswaran, Mukesh. 2009. What determines female autonomy? Evidence from Bangladesh. Journal of Development Economics, 90, 179-191.

Angrist, Joshua D., \& Pischke, Jorn-Steffen. 2009. Mostly Harmless Econometrics: An Empiricist's Companion. Princeton, New Jersey: Princeton University Press.

Attanasio, Orazio, \& Lechene, V. 2002. Testing of income pooling in household decisions. Review of Economic Dynamics, 5(4), 720-748.

Becker, Gary. 1960. An Economic Analysis of Fertility. Pages 209-240 of: Coaley, Ansley J (ed), Demographic and Economic Change in Developed Countries. Princeton University Press.

Becker, Gary, \& Lewis, HG. 1973. On the interaction between the quantity and quality of children. Journal of Political Economy, 81, S279-S288.

Becker, Gary, \& Mulligan, CB. 1997. The endogenous determination of time preference. Quarterly Journal of Economics, 112, 729-758.

Becker, GS. 1991. A Treatise on the Family. 2nd edn. Cambridge, MA: Harvard University Press.

Bertrand, Marianne, Duflo, Esther, \& Mullainathan, Sendhil. 2004. How Much Should We Trust Differences-in-Differences Estimation? Quarterly Journal of Economics, 119(1), 249-275.

Breierova, Lucia, \& Duflo, Esther. 2004. The Impact of Education on Fertility and Child Mortality: Do Fathers Really Matter Less Than Mothers. NBER Working Paper No 10513.

Bulatao, Rodolfo A. 1998. The Value of Family Planning Programs in Developing Countries. Tech. rept. RAND, Santa Monica, CA.

Buvinić, Mayra, Furst-Nichols, Rebecca, \& Pryor, Emily Courey. 2013. A RoadMap for Promoting Women's Economic Empowerment. Tech. rept. United Nations Foundation and Exxon Mobile.

Cameron, Colin A., \& Trivedi, Pravin K. 2005. Microeconometrics: methods and Applications. Cambridge, UK: Cambridge University Press. 
Cameron, Colin A., Gelbach, Jonah B., \& Miller, Douglas L. 2008. Bootstrap-based Improvements for Inference with Clustered Errors. Review of Economics and Statistics, 90(3), 414-427.

Carballido, Elvira Hernández. 2008. Medios de Comunicación, Sexualidad y Juventud. Pages 211-232 of: Stern, Claudio (ed), Adolescentes en México: Investigación, experiencias y estrategias para mejorar su salud reproductiva. El Colegio de México,Population Council and UNFPA.

Cremin, I, Mushati, P, Hallett, T, Mupambireyi, Z, Nyamukapa, C, Garnett, G P, \& Gregson, S. 2009. Measuring trends in age at first sex and age at marriage in Manicaland, Zimbabwe. Sex Transm Infect, 85(Suppl I), i34-i40.

Cuervo, Alfonso, Mora, César, \& García-Salcedo, R. 2009. Análisis de la Reforma Educativa en la Educación Secundaria en México e implicaciones del nuevo plan de estudios en la materia de Ciencias II. Lat. Am. J. Phys. Educ, 3(1), 158-166.

de Brauw, Alan, Gilligan, Daniel O., Hoddinott, John, \& Roy, Shalini. 2013. The Impact of Bolsa Famlia on Womens Decision-Making Power. World Development, In press.

de Walque, Damien. 2007. How does the impact of an HIV/AIDS information campaign vary with educational attainment? Evidence from rural Uganda. Journal of Development Economics, 84(2), 686-714.

Dinçer, Mehmet Alper, Kaushal, Neeraj, \& Grossman, Michael. 2013. Women's Education: Harbinger of Another Spring? Evidence from a Natural Experiment in Turkey. NBER Working Paper No. $1959 \%$.

Duflo, Esther. 2001. Schooling and Labor Market Consequences of School Construction in Indonesia: Evidence from an Unusual Policy Experiment. American Economic Review, 91(4), 795-813.

Duflo, Esther. 2012. Women Empowerment and Economic Development. Journal of Economic Literature, 50(4), 1051-1079.

Duflo, Esther, Banerjee, Abhijit, Glennerster, Rachel, \& Kinnan, Cynthia G. 2013. The Miracle of Microfinance? Evidence from a Randomized Evaluation. NBER Working Paper No. 18950.

Gitter, Seth R., \& Barham, Bradford L. 2008. Women's Power, Conditional Cash Transfers, and Schooling in Nicaragua. The World Bank Economic Review, 22(2), 271-290.

Grossman, Michael. 2006. Education and Nonmarket Outcomes. Pages 578-633 of: Handbook of the Economics of Education, Volume 2. Elsevier.

Grossman, Michael, \& Kaestner, Robert. 1997. Effects of Education on Health. Pages 69-123 of: Behrman, J.R., \& Stacey, N. (eds), The social benefits of education. Ann Arbor, MI: University of Michigan Press. 
Handa, S, Peterman, A., Davis, B, \& Stampini, M. 2009. Opening up Pandora's box: The effect of gender targeting and conditionality on household spending behavior in Mexico's PROGRESA program. World Development, 37(6), 1129-1142.

INEGI. 2002. Encuesta para el programa gente joven de MEXFAM 2002. México, D.F., Mexico: Fundación Mexicana para la Planeación Familiar (MEXFAM).

INEGI. 2012a. Encuesta Nacional de la Dinámica Demográfica 2009. Panorama sociodemográfico de México. Principales resultados. Mexico: Instituto Nacional de Estadística y Geografía, INEGI.

INEGI. 2012b. Mujeres y hombres en México 2011. Mexico: Instituto Nacional de Estadística y Geografía, INEGI.

Juárez, Fátima, Palma, José Luis, Singh, Susheela, \& Bankole, Akinrinola. 2010. Las Necesidades de Salud Sexual y Reproductiva de las Adolescentes en México: Retos y Oportunidades. Guttmacher Institute.

Kenkel, Donald S. 1991. Health Behavior, Health Knowledge and Schooling. Journal of Political Economy, 99(21), 287-305.

Lavy, Victor, \& Zablotsky, Alexander. 2011. Mother's Schooling and Fertility under Low Female Labor Force Participation: Evidence from a Natural Experiment. NBER Working Paper No.16856.

Levinson, Bradley A. 1999. Una etapa siempre difícil: Concepts of Adolescence and Secondary Education in Mexico. Comparative Education Review, 43(2), 129-61.

Michael, RT. 1973. Education and the derived demand for children. Journal of Political Economy, 81, S128-S164.

Mocan, Naci H., \& Cannonier, Colin. 2012. Empowering Women Through Education: Evidence from Sierra Leone. NBER Working Paper No. 18016.

Osili, Una Okonkwo, \& Long, Bridget Terry. 2008. Does Female Schooling Reduce Fertility? Evidence from Nigeria. Journal of Development Economics, 87(1), 57-75.

Perez-Arce, Franciso. 2011. The Effect of Education on Time Preferences. RAND WP No.8448.

Poder Ejecutivo Federal. 1999. Plan Nacional de Desarrollo 1989 - 1994. Tech. rept. Presidencia de la República, Mexico.

Rosenzweig, Mark R. 1995. Why are there returns to schooling? American Economic Review, 85(2), 153-158.

Rosenzweig, Mark R, \& Schultz, Paul. 1989. Schooling, Information and Non-Market Productivity: Contraceptive Use and Its Effectiveness. International Economic Review, 30(2), 457-477. 
Rubalcava, Luis, Teruel, Graciela, \& Thomas, Duncan. 2009. Investments, time preferences, and public transfers paid to women. Economic Development and Cultural Change, $\mathbf{5 7}(3), 507-538$.

Schiavon, Raffaella. 2008. Salud Sexual y Reproductiva del Adolescente. Pages 301323 of: Stern, Claudio (ed), Adolescentes en México: Investigación, experiencias y estrategias para mejorar su salud reproductiva. El Colegio de México,Population Council and UNFPA.

Singh, Susheela, \& Darroch, Jacqueline E. 2012. Adding it Up: Costs and Benefits of Contraceptive Services. Tech. rept. Guttmacher Institute and UNFPA.

Skirbekk, Vegard. 2008. Fertility Trends by Social Status. Demographic Research, 18(5), 145-180.

Stock, James H., H, Jonathan, \& Yogo, Motohiro. 2002. A Survey of Weak Instruments and Weak Identification in Generalized Method of Moments. Journal of Business and Economic Statistics, 20(4), 518-529.

Telmex. 1999. Informe Anual, 1999. Tech. rept. Teléfonos de México.

Trussell, J. 2011. Contraceptive efficacy. Pages 779-863 of: Hatcher, RA, Trussell, J, Nelson, AL, Cates, W, Kowal, D, \& Policar, M (eds), Contraceptive Technology: Twentieth Revised Edition. New York, NY: Ardent Media.

United Nations. 2011. World Population Prospects: The 2010 Revision (comprehensive Excel tables). New York: United Nations, Department of Economic and Social Affairs, Population Division.

Willis, RJ. 1973. A new approach to the economic theory of fertility behavior. Journal of Political Economy, 81, S14-S64.

World Health Organization. 2011. Universal access to reproductive health. Accelerated actions to enhance progress on Millennium Development Goal 5 through advancing Target 5B. Tech. rept. World Health Organization, Geneva, Switzerland.

World Health Organization. 2012 (July). Family Planning. Fact Sheet No 351.

World Health Organization and Johns Hopkins Bloomberg School of Public Health. 2011. Family Planning: A Global Handbook for Providers, 2011 Update. CCP and WHO, Baltimore, MD, and Geneva. 


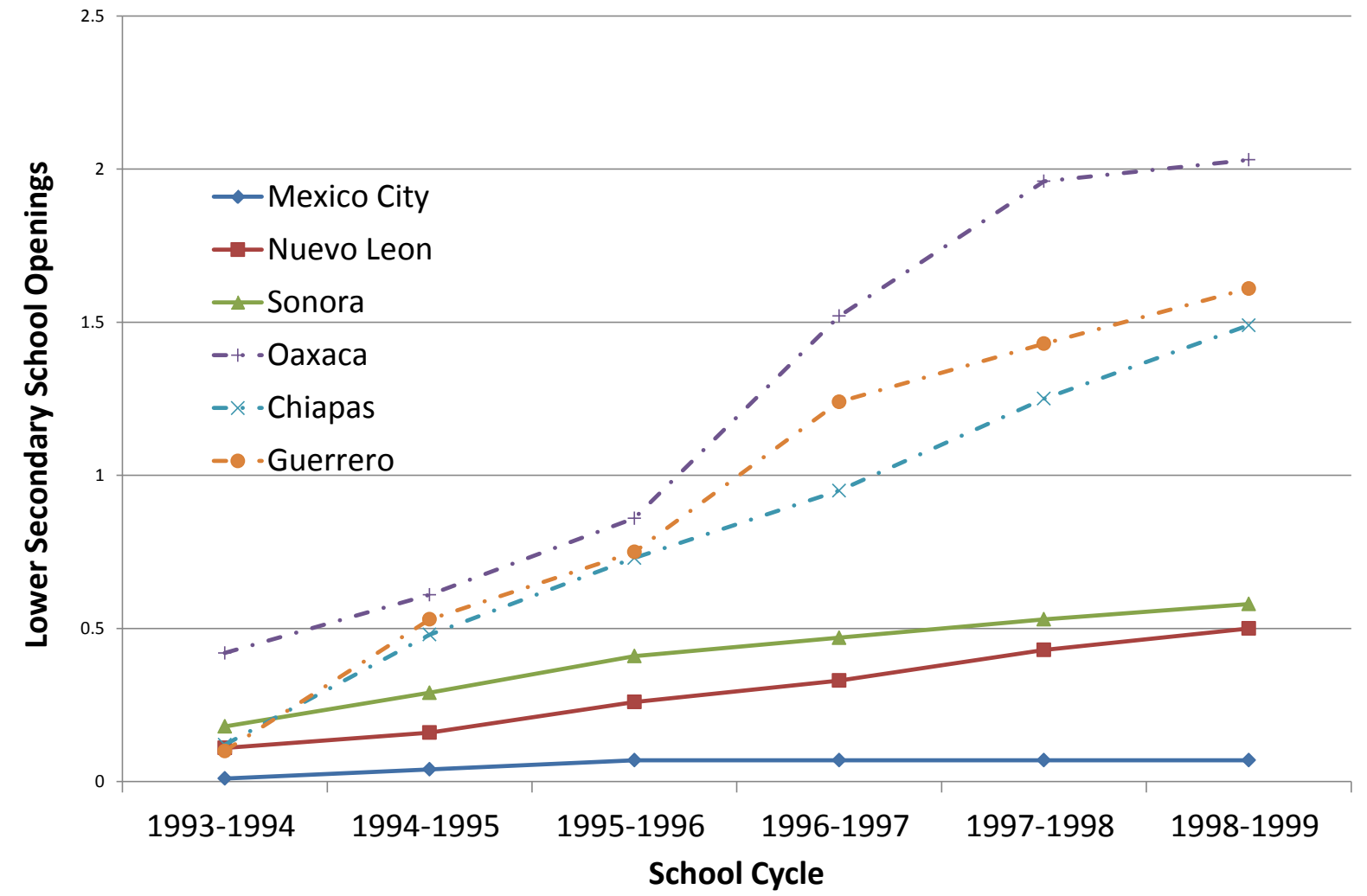

Figure 1: Cumulative Number of Lower Secondary School Openings per Thousand Children Aged 12-14 by School Cycle and State (Mexico City, Nuevo Leon and Sonora are rich states. The others are poor states.) 


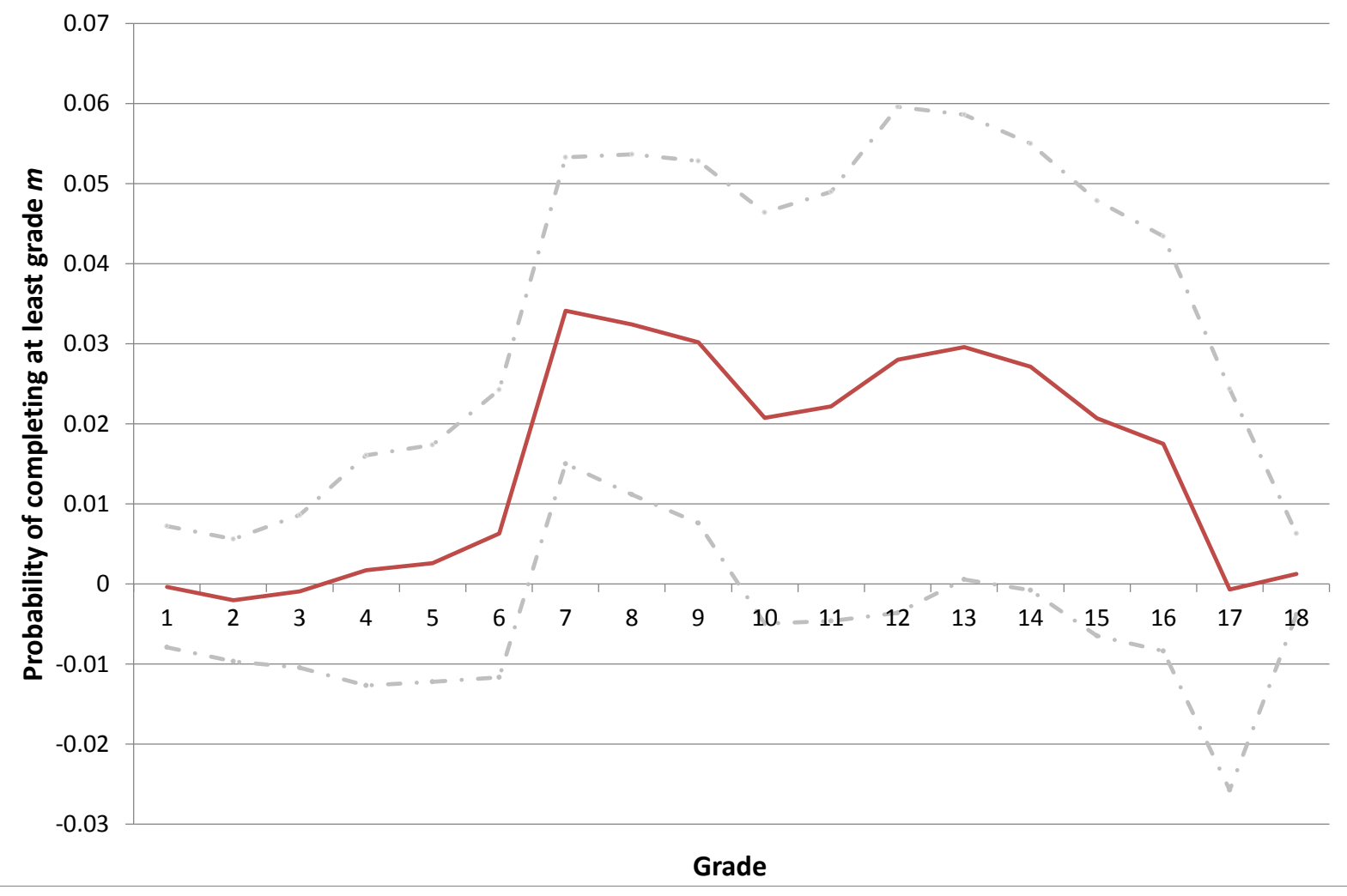

Figure 2: Effect of the Education Reform on the Probability of Completing Grade $m$ for Women 
Table 1: Sample means by treatment status

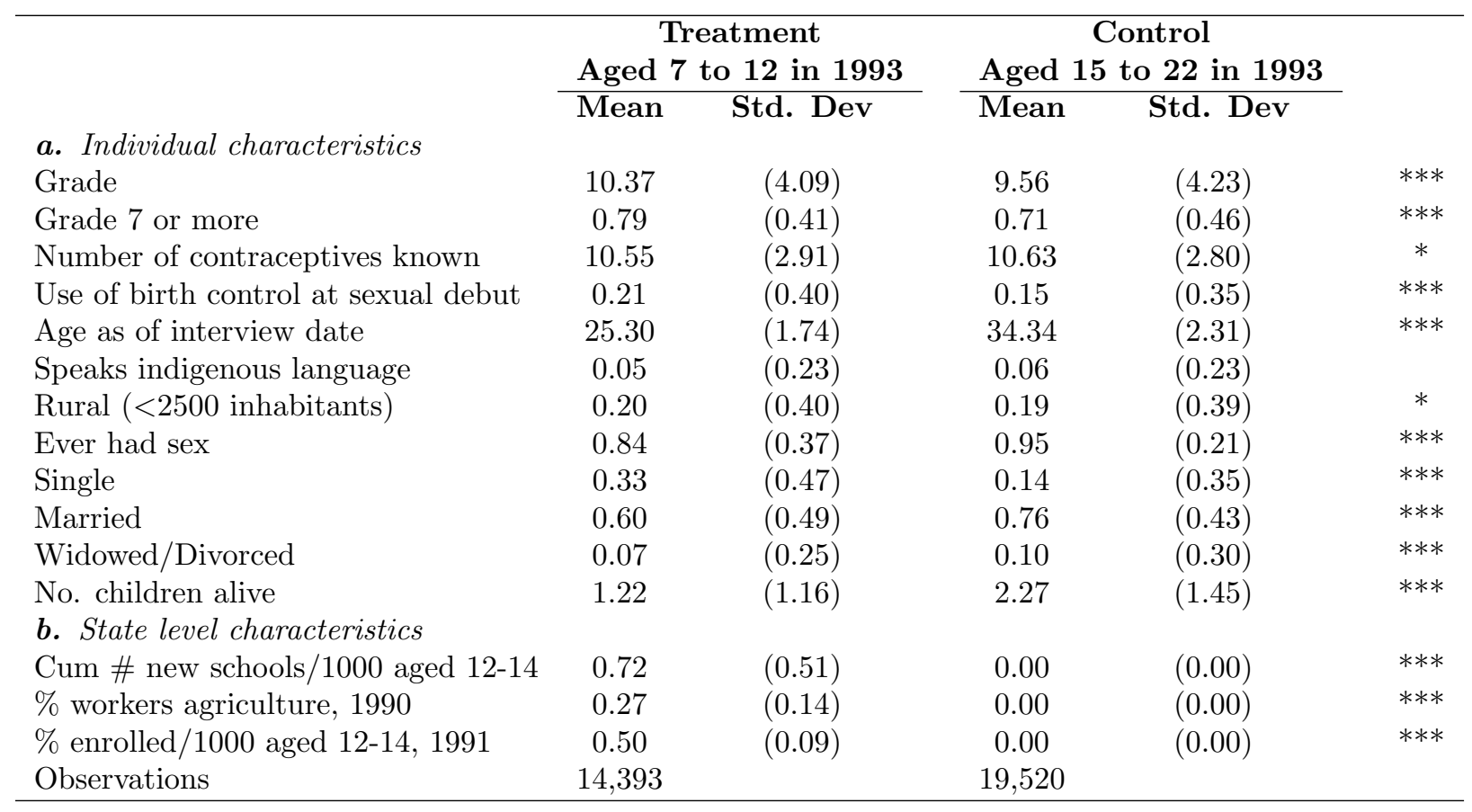

Notes: Stars denote significant differences between treatment and control groups. ${ }^{* * *} \mathrm{p}<0.001,{ }^{* *} \mathrm{p}<0.01$, $* \mathrm{p}<0.05$ 
Table 2: First Stage: Effect of Education Reform on Schooling

\begin{tabular}{|c|c|c|c|c|c|}
\hline $\mathrm{T}^{*}$ Cum \# new schools/1000 aged 12-14 & $\begin{array}{c}(1) \\
0.034^{* * *} \\
(0.009)\end{array}$ & $\begin{array}{c}(2) \\
0.034^{* *} \\
(0.009)\end{array}$ & $\begin{array}{c}(3) \\
0.034^{* *} \\
(0.010)\end{array}$ & $\begin{array}{c}(4) \\
0.032^{* *} \\
(0.009)\end{array}$ & $\begin{array}{c}(5) \\
0.032^{* *} \\
(0.009)\end{array}$ \\
\hline Speaks indigenous language & $\begin{array}{c}-0.295^{* * *} \\
(0.016)\end{array}$ & $\begin{array}{c}-0.295^{* * *} \\
(0.016)\end{array}$ & $\begin{array}{c}-0.292^{* * *} \\
(0.016)\end{array}$ & $\begin{array}{c}-0.253^{* * *} \\
(0.018)\end{array}$ & $\begin{array}{c}-0.247^{* * *} \\
(0.018)\end{array}$ \\
\hline Rural (<2500 inhabitants) & $\begin{array}{c}-0.237^{* * *} \\
(0.015)\end{array}$ & $\begin{array}{c}-0.236^{* * *} \\
(0.015)\end{array}$ & $\begin{array}{c}-0.230^{* * *} \\
(0.015)\end{array}$ & $\begin{array}{c}-0.199^{* * *} \\
(0.012)\end{array}$ & $\begin{array}{c}-0.195^{* * *} \\
(0.012)\end{array}$ \\
\hline$\%$ workers agriculture, 1990 & $\begin{array}{l}-0.009 \\
(0.044)\end{array}$ & $\begin{array}{c}-0.012 \\
(0.044)\end{array}$ & $\begin{array}{l}-0.009 \\
(0.045)\end{array}$ & $\begin{array}{c}-0.018 \\
(0.044)\end{array}$ & $\begin{array}{l}-0.012 \\
(0.044)\end{array}$ \\
\hline \% enrolled/1000 aged 12-14, 1991 & $\begin{array}{l}-0.130^{*} \\
(0.058)\end{array}$ & $\begin{array}{c}-0.131^{*} \\
(0.058)\end{array}$ & $\begin{array}{l}-0.147^{*} \\
(0.058)\end{array}$ & $\begin{array}{r}-0.097+ \\
(0.055)\end{array}$ & $\begin{array}{l}-0.082 \\
(0.056)\end{array}$ \\
\hline Ever had sex & & $\begin{array}{c}-0.042^{* * *} \\
(0.010)\end{array}$ & & & $\begin{array}{c}0.082^{* * *} \\
(0.012)\end{array}$ \\
\hline Married & & & $\begin{array}{c}-0.076^{* * *} \\
(0.007)\end{array}$ & & $\begin{array}{c}0.018^{* *} \\
(0.006)\end{array}$ \\
\hline Widowed/Divorced & & & $\begin{array}{c}-0.052^{* * *} \\
(0.012)\end{array}$ & & $\begin{array}{c}0.031^{*} \\
(0.013)\end{array}$ \\
\hline No. children alive & & & & $\begin{array}{c}-0.072^{* * *} \\
(0.004)\end{array}$ & $\begin{array}{c}-0.082^{* * *} \\
(0.004)\end{array}$ \\
\hline Constant & $\begin{array}{c}0.887^{* * *} \\
(0.042)\end{array}$ & $\begin{array}{c}0.921^{* * *} \\
(0.044)\end{array}$ & $\begin{array}{c}0.940^{* * *} \\
(0.044)\end{array}$ & $\begin{array}{c}0.948^{* * *} \\
(0.040)\end{array}$ & $\begin{array}{c}0.876^{* * *} \\
(0.042)\end{array}$ \\
\hline F-First stage & 13.23 & 13.02 & 12.58 & 12.11 & 12.55 \\
\hline Observations & 33,913 & 33,913 & 33,913 & 33,913 & 33,913 \\
\hline
\end{tabular}

Notes: Clustered SE at state level in parentheses. ${ }^{* * *} \mathrm{p}<0.001,{ }^{* *} \mathrm{p}<0.01,{ }^{*} \mathrm{p}<0.05{ }^{+} \mathrm{p}<0.1$. Regressions also include cohort and state of birth fixed effects. The instrument ( $\mathrm{T}^{*} \mathrm{Cum} \#$ new schools/1000 aged 12-14) is the interaction between treatment status (treatment if aged 7 to 12 in 1993 and control if aged 15 to 22 in 1993) and the cumulative number of public lower secondary schools in the state of birth when women were 12 years. 


\section{Table 3: Effect of Schooling on Number of Contraceptives Known}

\begin{tabular}{|c|c|c|c|c|c|}
\hline \multirow{2}{*}{\multicolumn{6}{|c|}{ OLS: Association between schooling and the number of contraceptives known }} \\
\hline & & & & & \\
\hline Grade 7 or more & $\begin{array}{c}2.134^{* * *} \\
(0.074)\end{array}$ & $\begin{array}{c}2.154^{* * *} \\
(0.073)\end{array}$ & $\begin{array}{c}2.153^{* * *} * \\
(0.075)\end{array}$ & $\begin{array}{c}2.093^{* * *} * \\
(0.074)\end{array}$ & $\begin{array}{c}2.042^{* * *} \\
(0.069)\end{array}$ \\
\hline Speaks indigenous language & $\begin{array}{c}-2.075^{* * *} \\
(0.397)\end{array}$ & $\begin{array}{c}-2.065^{* * *} \\
(0.397)\end{array}$ & $\begin{array}{c}-2.079 * * * \\
(0.397)\end{array}$ & $\begin{array}{c}-2.053 * * * \\
(0.393)\end{array}$ & $\begin{array}{c}-2.001^{* * * *} \\
(0.389)\end{array}$ \\
\hline Rural ( $<2500$ inhabitants) & $\begin{array}{c}-1.015^{* * *} \\
(0.102)\end{array}$ & $\begin{array}{c}-1.015^{* * *} \\
(0.100)\end{array}$ & $\begin{array}{c}-1.029^{* * *} * \\
(0.103)\end{array}$ & $\begin{array}{c}-0.994^{* * *} * \\
(0.102)\end{array}$ & $\begin{array}{c}-0.957^{* * * *} \\
(0.098)\end{array}$ \\
\hline \% workers agriculture, 1990 & $\begin{array}{c}0.225 \\
(0.267)\end{array}$ & $\begin{array}{c}0.298 \\
(0.272)\end{array}$ & $\begin{array}{c}0.232 \\
(0.265)\end{array}$ & $\begin{array}{c}0.216 \\
(0.267)\end{array}$ & $\begin{array}{c}0.295 \\
(0.272)\end{array}$ \\
\hline \% enrolled/1000 aged 12-14, 1991 & $\begin{array}{l}1.135^{* *} \\
(0.388)\end{array}$ & $\begin{array}{l}1.175^{* *} \\
(0.387)\end{array}$ & $\begin{array}{l}1.203^{* *} \\
(0.382)\end{array}$ & $\begin{array}{l}1.158^{* *} \\
(0.386)\end{array}$ & $\begin{array}{l}1.251^{* *} \\
(0.378)\end{array}$ \\
\hline Ever had sex & & $\begin{array}{c}0.918^{* * *} \\
(0.091)\end{array}$ & & & $\begin{array}{c}1.194^{* * *} * \\
(0.089)\end{array}$ \\
\hline Married & & & $\begin{array}{c}0.259^{* * *} \\
(0.060)\end{array}$ & & $\begin{array}{c}0.010 \\
(0.043)\end{array}$ \\
\hline Widowed/Divorced & & & $\begin{array}{c}0.248^{* *} \\
(0.072)\end{array}$ & & $\begin{array}{l}-0.015 \\
(0.059)\end{array}$ \\
\hline No. children alive & & & & $\begin{array}{c}-0.059^{* *} \\
(0.019)\end{array}$ & $\begin{array}{c}-0.167^{* * * *} \\
(0.016)\end{array}$ \\
\hline Constant & $\begin{array}{c}8.188^{* * *} \\
(0.271)\end{array}$ & $\begin{array}{c}7.432^{* * *} \\
(0.297)\end{array}$ & $\begin{array}{c}7.986^{* * *} \\
(0.275)\end{array}$ & $\begin{array}{c}8.273^{* * *} \\
(0.271)\end{array}$ & $\begin{array}{c}7.443^{* * * *} \\
(0.296)\end{array}$ \\
\hline R-squared & 0.250 & 0.258 & 0.251 & 0.250 & 0.263 \\
\hline \multicolumn{6}{|c|}{ IV: Effect of schooling on the number of contraceptives known } \\
\hline Grade 7 or more & $\begin{array}{c}4.152^{*} \\
(1.871)\end{array}$ & $\begin{array}{l}4.216^{*} \\
(1.854)\end{array}$ & $\begin{array}{c}4.225^{*} \\
(1.878)\end{array}$ & $\begin{array}{l}4.252^{*} \\
(2.009)\end{array}$ & $\begin{array}{c}4.200^{*} \\
(1.990)\end{array}$ \\
\hline Speaks indigenous language & $\begin{array}{c}-1.480^{*} \\
(0.696)\end{array}$ & $\begin{array}{c}-1.457^{*} \\
(0.688)\end{array}$ & $\begin{array}{c}-1.475^{*} \\
(0.693)\end{array}$ & $\begin{array}{c}-1.506^{*} \\
(0.661)\end{array}$ & $\begin{array}{c}-1.467^{*} \\
(0.644)\end{array}$ \\
\hline Rural ( $<2500$ inhabitants) & $\begin{array}{c}-0.538 \\
(0.436)\end{array}$ & $\begin{array}{l}-0.527 \\
(0.428)\end{array}$ & $\begin{array}{l}-0.551 \\
(0.427)\end{array}$ & $\begin{array}{c}-0.564 \\
(0.394)\end{array}$ & $\begin{array}{c}-0.536 \\
(0.381)\end{array}$ \\
\hline \% workers agriculture, 1990 & $\begin{array}{c}0.193 \\
(0.272)\end{array}$ & $\begin{array}{c}0.272 \\
(0.270)\end{array}$ & $\begin{array}{c}0.201 \\
(0.270)\end{array}$ & $\begin{array}{c}0.206 \\
(0.264)\end{array}$ & $\begin{array}{c}0.272 \\
(0.269)\end{array}$ \\
\hline \% enrolled/1000 aged 12-14, 1991 & $\begin{array}{c}1.485^{* * *} \\
(0.388)\end{array}$ & $\begin{array}{c}1.536^{* * *} \\
(0.387)\end{array}$ & $\begin{array}{c}1.599^{* * *} \\
(0.395)\end{array}$ & $\begin{array}{c}1.454^{* * * *} \\
(0.377)\end{array}$ & $\begin{array}{c}1.517^{* * * *} \\
(0.361)\end{array}$ \\
\hline Ever had sex & & $\begin{array}{c}1.005^{* * *} \\
(0.125)\end{array}$ & & & $\begin{array}{c}1.017^{* * *} \\
(0.170)\end{array}$ \\
\hline Married & & & $\begin{array}{c}0.417^{* *} \\
(0.157)\end{array}$ & & $\begin{array}{l}-0.029 \\
(0.062)\end{array}$ \\
\hline Widowed/Divorced & & & $\begin{array}{c}0.355^{* *} \\
(0.127)\end{array}$ & & $\begin{array}{c}-0.082 \\
(0.080)\end{array}$ \\
\hline No. children alive & & & & $\begin{array}{c}0.096 \\
(0.145)\end{array}$ & $\begin{array}{c}0.009 \\
(0.163)\end{array}$ \\
\hline Constant & $\begin{array}{c}6.265^{* * *} \\
(1.690)\end{array}$ & $\begin{array}{c}5.398^{* *} \\
(1.748)\end{array}$ & $\begin{array}{c}5.904^{* *} \\
(1.795)\end{array}$ & $\begin{array}{c}6.095^{* *} \\
(1.931)\end{array}$ & $\begin{array}{c}5.423^{* *} \\
(1.782)\end{array}$ \\
\hline F-First Stage & 13.23 & 13.02 & 12.58 & 12.11 & 12.55 \\
\hline Hausman test p-value & 0.25 & 0.23 & 0.23 & 0.25 & 0.24 \\
\hline Observations & 33,913 & 33,913 & 33,913 & 33,913 & 33,913 \\
\hline
\end{tabular}

Notes: Clustered SE at state level in parentheses. ${ }^{* * *} \mathrm{p}<0.001,{ }^{* *} \mathrm{p}<0.01,{ }^{*} \mathrm{p}<0.05^{+} \mathrm{p}<0.1$. Regressions also include cohort and state of birth fixed effects. 
Table 4: Effect of Schooling on Use of Birth Control at Sexual Debut

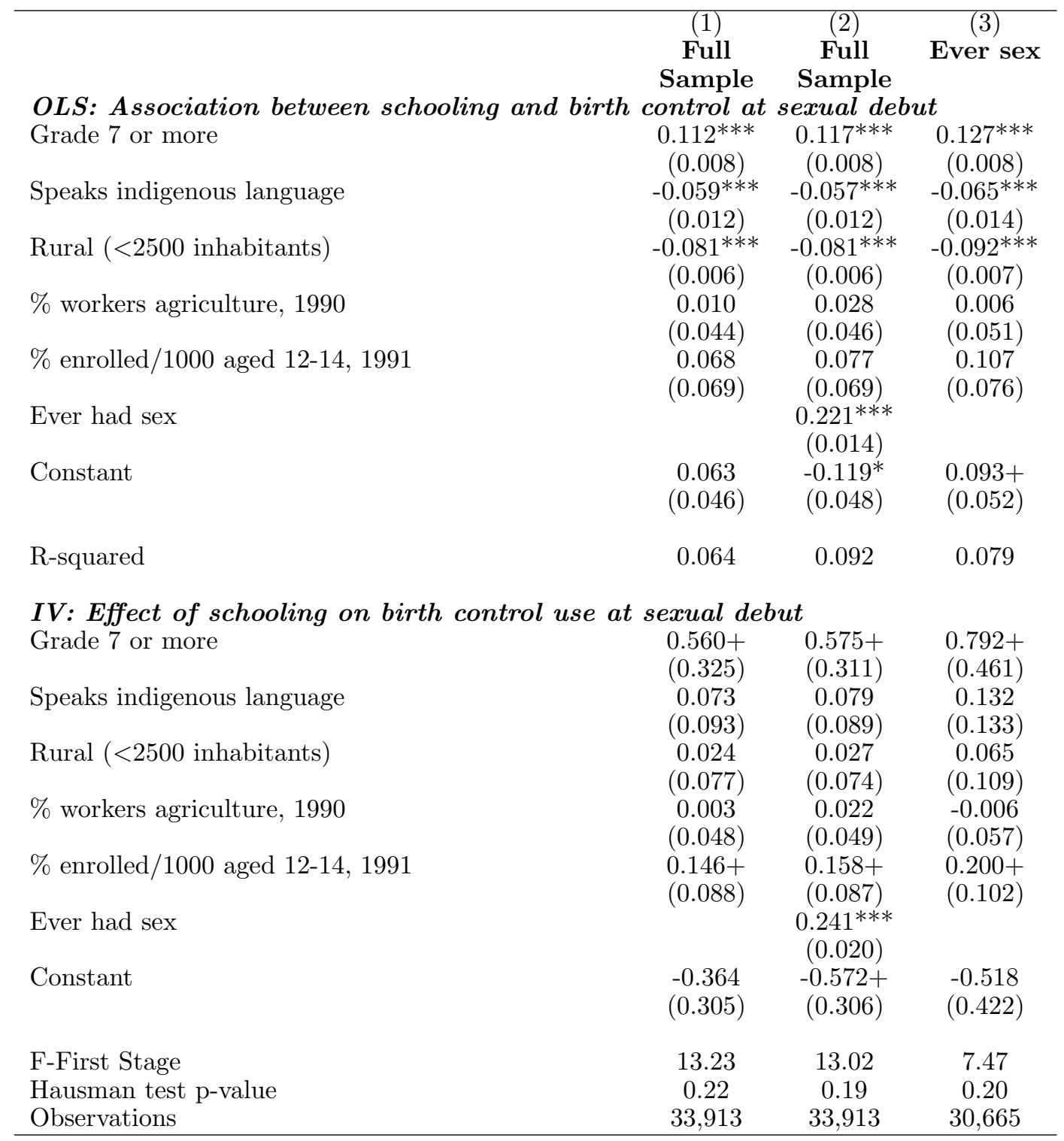

Notes: Clustered SE at state level in parentheses. ${ }^{* * *} \mathrm{p}<0.001,{ }^{* *} \mathrm{p}<0.01,{ }^{*} \mathrm{p}<0.05^{+} \mathrm{p}<0.1$. Regressions also include cohort and state of birth fixed effects. 
Table 5: The Effect of Schooling on Number of Contraceptives Known and Use of Birth Control At Sexual Debut by Population Sub-groups

\begin{tabular}{|c|c|c|c|c|}
\hline & $\begin{array}{c}(1) \\
\text { All } \\
\text { women }\end{array}$ & $\begin{array}{c}(2) \\
\text { Non } \\
\text { Indigenous }\end{array}$ & $\begin{array}{c}(3) \\
\text { Urban }\end{array}$ & $\begin{array}{c}(4) \\
\text { Rural }\end{array}$ \\
\hline \multicolumn{5}{|c|}{ A: First stage effect of education reform on schooling } \\
\hline $\mathrm{T}^{*}$ Cum \# new schools/1000 aged 12-14 & $\begin{array}{c}0.034^{* * *} \\
(0.009)\end{array}$ & $\begin{array}{r}0.029^{* *} \\
(0.010)\end{array}$ & $\begin{array}{c}0.022^{* *} \\
(0.008)\end{array}$ & $\begin{array}{l}0.065^{*} \\
(0.026)\end{array}$ \\
\hline F-First Stage & 13.23 & 9.40 & 8.20 & 6.43 \\
\hline \multicolumn{5}{|c|}{$\begin{array}{l}\text { B. Outcome is number of contraceptives known } \\
\text { OLS }\end{array}$} \\
\hline Grade 7 or more & $\begin{array}{c}2.134^{* * *} \\
(0.074)\end{array}$ & $\begin{array}{c}2.110^{* * *} \\
(0.076)\end{array}$ & $\begin{array}{c}2.166^{* * *} \\
(0.080)\end{array}$ & $\begin{array}{c}1.978^{* * *} \\
(0.112)\end{array}$ \\
\hline R-squared & 0.25 & 0.193 & 0.189 & 0.234 \\
\hline \multicolumn{5}{|l|}{$I V$} \\
\hline Grade 7 or more & $\begin{array}{l}4.152^{*} \\
(1.871)\end{array}$ & $\begin{array}{l}4.834+ \\
(2.627)\end{array}$ & $\begin{array}{c}2.764 \\
(3.640)\end{array}$ & $\begin{array}{l}7.389+ \\
(3.774)\end{array}$ \\
\hline Hausman test p-value & 0.25 & 0.22 & 0.87 & 0.10 \\
\hline \multicolumn{5}{|c|}{$\begin{array}{l}\text { C. Outcome is use of birth control at sexual debut } \\
\text { OLS }\end{array}$} \\
\hline Grade 7 or more & $\begin{array}{c}0.112^{* * *} \\
(0.008)\end{array}$ & $\begin{array}{c}0.116^{* * *} \\
(0.008)\end{array}$ & $\begin{array}{c}0.135^{* * *} \\
(0.008)\end{array}$ & $\begin{array}{c}0.053^{* * *} \\
(0.010)\end{array}$ \\
\hline R-squared & 0.064 & 0.059 & 0.051 & 0.040 \\
\hline \multicolumn{5}{|l|}{$I V$} \\
\hline Grade 7 or more & $\begin{array}{l}0.560+ \\
(0.325)\end{array}$ & $\begin{array}{l}0.654+ \\
(0.377)\end{array}$ & $\begin{array}{c}0.434 \\
(0.502)\end{array}$ & $\begin{array}{l}0.868^{*} \\
(0.409)\end{array}$ \\
\hline Hausman test p-value & 0.22 & 0.22 & 0.59 & 0.02 \\
\hline Observations & 33,913 & 32,065 & 27,263 & 6,650 \\
\hline
\end{tabular}

Notes: Clustered SE at state level in parentheses. ${ }^{* * *} \mathrm{p}<0.001,{ }^{* *} \mathrm{p}<0.01,{ }^{*} \mathrm{p}<0.05{ }^{+} \mathrm{p}<0.1$. Regressions include the controls listed in equation (2) in the text. 


\section{Table 6: Sensitivity Analysis of First Stage: Effect of Education Reform on}

Schooling

\begin{tabular}{|c|c|c|c|c|}
\hline & $\begin{array}{c}(1) \\
\text { Control } \\
\mathbf{1 6 - 2 2}\end{array}$ & $\begin{array}{c}(2) \\
\text { Treatment } \\
\mathbf{1 3 - 1 4}\end{array}$ & $\begin{array}{c}(3) \\
\text { Private } \\
\text { schools }\end{array}$ & $\begin{array}{c}\text { (4) } \\
\text { Includes } \\
\text { pupil to } \\
\text { teacher }\end{array}$ \\
\hline $\mathrm{T}^{*}$ Cum \# new schools/1000 aged 12-14 & $\begin{array}{c}0.032^{* *} \\
(0.009)\end{array}$ & $\begin{array}{c}0.021 \\
(0.017)\end{array}$ & $\begin{array}{c}-0.129 \\
(0.096)\end{array}$ & $\begin{array}{c}0.033^{* *} \\
(0.010)\end{array}$ \\
\hline Speaks indigenous language & $\begin{array}{c}-0.295^{* * *} \\
(0.016)\end{array}$ & $\begin{array}{c}-0.307^{* * *} \\
(0.020)\end{array}$ & $\begin{array}{c}-0.295^{* * *} \\
(0.016)\end{array}$ & $\begin{array}{c}-0.295^{* * *} \\
(0.016)\end{array}$ \\
\hline Rural ( $<2500$ inhabitants) & $\begin{array}{c}-0.237^{* * *} \\
(0.015)\end{array}$ & $\begin{array}{c}-0.279^{* * *} \\
(0.017)\end{array}$ & $\begin{array}{c}-0.237^{* * *} \\
(0.015)\end{array}$ & $\begin{array}{c}-0.237^{* * *} \\
(0.015)\end{array}$ \\
\hline \% workers agriculture, 1990 & $\begin{array}{c}-0.002 \\
(0.050)\end{array}$ & $\begin{array}{c}0.004 \\
(0.076)\end{array}$ & $\begin{array}{c}-0.007 \\
(0.053)\end{array}$ & $\begin{array}{c}-0.021 \\
(0.046)\end{array}$ \\
\hline \% enrolled/1000 aged 12-14, 1991 & $\begin{array}{r}-0.125+ \\
(0.065)\end{array}$ & $\begin{array}{c}0.000 \\
(0.103)\end{array}$ & $\begin{array}{c}-0.170 * * \\
(0.056)\end{array}$ & $\begin{array}{c}-0.119^{*} \\
(0.058)\end{array}$ \\
\hline Pupil to teacher ratio, 1990 & & & & $\begin{array}{l}-0.001 \\
(0.001)\end{array}$ \\
\hline Constant & $\begin{array}{c}0.896^{* * *} \\
(0.048)\end{array}$ & $\begin{array}{c}0.764^{* * *} \\
(0.009)\end{array}$ & $\begin{array}{c}0.966^{* * *} \\
(0.039)\end{array}$ & $\begin{array}{c}0.931^{* * *} \\
(0.058)\end{array}$ \\
\hline F-First stage & 11.38 & 1.463 & 1.80 & 11.60 \\
\hline Observations & 31,693 & 22,001 & 33,913 & 33,913 \\
\hline
\end{tabular}

Notes: Clustered SE at state level in parentheses. ${ }^{* * *} \mathrm{p}<0.001,{ }^{* *} \mathrm{p}<0.01,{ }^{*} \mathrm{p}<0.05$. Regressions also include cohort and state of birth fixed effects. In all columns, except for column 3 the instrument ( $\mathrm{T}^{*}$ Cum \# new schools/1000 aged 12-14) is the interaction between treatment status and the cumulative number of public lower secondary schools in the state of birth when women were 12 years. In column 3 the instrument is the interaction between treatment status and the cumulative number of private lower secondary schools in the state of birth when women were 12 years. In column 1 Treatment=1 if age in 1993 is 7 to 12 and Treatment=0 if age in 1993 is 16 to 22 . In column 2 Treatment=1 if age in 1993 is 13 or 14 and Treatment $=0$ if age in 1993 is 15 to 22 . In columns 3 and 4 Treatment=1 if age in 1993 is 7 to 12 and Treatment $=0$ if age in 1993 is 15 to 22. 
Table 7: Sensitivity Analysis of Second Stage: Effect of Schooling on Number of Contraceptives Known and Use of Birth Control At Sexual Debut

\begin{tabular}{|c|c|c|c|c|}
\hline & $(1)$ & $(2)$ & $(3)$ & $(4)$ \\
\hline & \multicolumn{2}{|c|}{ Knowledge } & \multicolumn{2}{|c|}{ Use at sexual debut } \\
\hline & $\begin{array}{c}\text { Control } \\
\text { Group } \\
15-17\end{array}$ & $\begin{array}{c}\text { Includes } \\
\text { medical } \\
\text { units }\end{array}$ & $\begin{array}{c}\text { Control } \\
\text { Group } \\
15-17\end{array}$ & $\begin{array}{c}\text { Includes } \\
\text { medical } \\
\text { units }\end{array}$ \\
\hline \multicolumn{5}{|c|}{ OLS: Association between schooling and contraceptive knowledge and use } \\
\hline Grade 7 or more & $\begin{array}{c}2.284^{* * *} \\
(0.071)\end{array}$ & $\begin{array}{c}2.134^{* * *} \\
(0.074)\end{array}$ & $\begin{array}{c}0.122^{* * *} \\
(0.008)\end{array}$ & $\begin{array}{c}0.112^{* * *} \\
(0.008)\end{array}$ \\
\hline Speaks indigenous language & $\begin{array}{c}-2.102^{* * *} \\
(0.394)\end{array}$ & $\begin{array}{c}-2.075^{* * *} \\
(0.397)\end{array}$ & $\begin{array}{c}-0.068^{* * *} \\
(0.011)\end{array}$ & $\begin{array}{c}-0.059 * * * \\
(0.012)\end{array}$ \\
\hline Rural ( $<2500$ inhabitants) & $\begin{array}{c}-1.075^{* * *} \\
(0.114)\end{array}$ & $\begin{array}{c}-1.015^{* * *} \\
(0.102)\end{array}$ & $\begin{array}{c}-0.095^{* * *} \\
(0.006)\end{array}$ & $\begin{array}{c}-0.081^{* * *} \\
(0.006)\end{array}$ \\
\hline \% workers agriculture, 1990 & $\begin{array}{c}0.087 \\
(0.295)\end{array}$ & $\begin{array}{c}0.220 \\
(0.269)\end{array}$ & $\begin{array}{c}0.020 \\
(0.052)\end{array}$ & $\begin{array}{c}0.002 \\
(0.047)\end{array}$ \\
\hline$\%$ enrolled/1000 aged 12-14, 1991 & $\begin{array}{c}1.263^{* *} \\
(0.419)\end{array}$ & $\begin{array}{c}1.137^{* *} \\
(0.388)\end{array}$ & $\begin{array}{c}0.068 \\
(0.088)\end{array}$ & $\begin{array}{c}0.071 \\
(0.067)\end{array}$ \\
\hline Medical units/1000 individuals & & $\begin{array}{c}0.049 \\
(0.779)\end{array}$ & & $\begin{array}{c}0.092 \\
(0.139)\end{array}$ \\
\hline Constant & $\begin{array}{c}7.946^{* * *} \\
(0.279)\end{array}$ & $\begin{array}{c}8.180^{* * *} \\
(0.294)\end{array}$ & $\begin{array}{c}0.050 \\
(0.054)\end{array}$ & $\begin{array}{c}0.048 \\
(0.045)\end{array}$ \\
\hline R-squared & 0.260 & 0.250 & 0.063 & 0.064 \\
\hline \multicolumn{5}{|c|}{ IV: Effect of schooling on contraceptive knowledge and use } \\
\hline Grade 7 or more & $\begin{array}{c}5.797^{* *} \\
(2.179)\end{array}$ & $\begin{array}{c}4.026^{*} \\
(1.906)\end{array}$ & $\begin{array}{c}0.580 \\
(0.478)\end{array}$ & $\begin{array}{c}0.484 \\
(0.311)\end{array}$ \\
\hline Speaks indigenous language & $\begin{array}{l}-1.105 \\
(0.730)\end{array}$ & $\begin{array}{c}-1.517^{*} \\
(0.703)\end{array}$ & $\begin{array}{c}0.062 \\
(0.132)\end{array}$ & $\begin{array}{c}0.051 \\
(0.089)\end{array}$ \\
\hline Rural (<inhabitants) & $\begin{array}{c}-0.333 \\
(0.470)\end{array}$ & $\begin{array}{l}-0.568 \\
(0.445)\end{array}$ & $\begin{array}{c}0.002 \\
(0.102)\end{array}$ & $\begin{array}{c}0.006 \\
(0.073)\end{array}$ \\
\hline \% workers agriculture, 1990 & $\begin{array}{c}0.116 \\
(0.331)\end{array}$ & $\begin{array}{c}0.177 \\
(0.283)\end{array}$ & $\begin{array}{c}0.024 \\
(0.064)\end{array}$ & $\begin{array}{l}-0.006 \\
(0.049)\end{array}$ \\
\hline \% enrolled/1000 aged 12-14, 1991 & $\begin{array}{c}1.874^{* * *} \\
(0.537)\end{array}$ & $\begin{array}{c}1.470^{* * *} \\
(0.403)\end{array}$ & $\begin{array}{c}0.148 \\
(0.128)\end{array}$ & $\begin{array}{c}0.136 \\
(0.087)\end{array}$ \\
\hline Medical units/1000 individuals & & $\begin{array}{c}0.200 \\
(0.735)\end{array}$ & & $\begin{array}{c}0.122 \\
(0.134)\end{array}$ \\
\hline Constant & $\begin{array}{l}4.605^{*} \\
(1.975)\end{array}$ & $\begin{array}{c}6.354^{* * *} \\
(1.715)\end{array}$ & $\begin{array}{l}-0.385 \\
(0.452)\end{array}$ & $\begin{array}{l}-0.310 \\
(0.295)\end{array}$ \\
\hline F-First Stage & 6.06 & 16.03 & 6.06 & 16.03 \\
\hline Hausman test p-value & 0.12 & 0.28 & 0.34 & 0.28 \\
\hline Observations & 21,481 & 33,913 & 21,481 & 33,913 \\
\hline
\end{tabular}

Notes: Clustered SE at state level in parentheses. ${ }^{* * *} \mathrm{p}<0.001,{ }^{* *} \mathrm{p}<0.01,{ }^{*} \mathrm{p}<0.05$. Regressions also include cohort and state of birth fixed effects. Columns 1 and 3 exclude those aged 18 to 22 in 1993 from the control group. 


\section{Table A.1: Effect of Schooling on Number of Contraceptives Known based on}

Effectiveness

\begin{tabular}{|c|c|c|c|}
\hline & $\begin{array}{l}(1) \\
\text { All method }\end{array}$ & $\begin{array}{c}(2) \\
\text { Very effective }\end{array}$ & $\begin{array}{c}(3) \\
\text { Less effective }\end{array}$ \\
\hline \multicolumn{4}{|c|}{ OLS: Association between schooling and the number of contraceptives known } \\
\hline Grade 7 or more & $\begin{array}{l}2.134^{* *} \\
(0.074)\end{array}$ & $\begin{array}{c}1.060^{* * *} \\
(0.043)\end{array}$ & $\begin{array}{c}1.075^{* * *} \\
(0.034)\end{array}$ \\
\hline Speaks indigenous language & $\begin{array}{c}-2.075 * * * \\
(0.397)\end{array}$ & $\begin{array}{c}-1.258^{* * *} \\
(0.266)\end{array}$ & $\begin{array}{c}-0.817^{* * * *} \\
(0.135)\end{array}$ \\
\hline Rural ( $<2500$ inhabitants) & $\begin{array}{c}-1.015^{* * *} \\
(0.102)\end{array}$ & $\begin{array}{c}-0.512^{* * *} \\
(0.059)\end{array}$ & $\begin{array}{c}-0.504^{* * *} \\
(0.047)\end{array}$ \\
\hline \% workers agriculture, 1990 & $\begin{array}{l}0.225 \\
(0.267)\end{array}$ & $\begin{array}{c}0.009 \\
(0.161)\end{array}$ & $\begin{array}{c}0.216 \\
(0.134)\end{array}$ \\
\hline \% enrolled/1000 aged 12-14, 1991 & $\begin{array}{l}1.135^{* *} \\
(0.388)\end{array}$ & $\begin{array}{l}0.492^{*} \\
(0.236)\end{array}$ & $\begin{array}{c}0.643^{* *} \\
(0.197)\end{array}$ \\
\hline Constant & $\begin{array}{c}8.188^{* * * *} \\
(0.271)\end{array}$ & $\begin{array}{c}5.995^{* * * *} \\
(0.160)\end{array}$ & $\begin{array}{c}2.193^{* * * *} \\
(0.138)\end{array}$ \\
\hline R-squared & 0.25 & 0.215 & 0.215 \\
\hline \multicolumn{4}{|c|}{ IV: Effect of schooling on the number of contraceptives known } \\
\hline Grade 7 or more & $\begin{array}{l}4.152^{*} \\
(1.871)\end{array}$ & $\begin{array}{c}2.047^{*} \\
(1.041)\end{array}$ & $\begin{array}{l}2.105^{*} \\
(0.928)\end{array}$ \\
\hline Speaks indigenous language & $\begin{array}{l}-1.480^{*} \\
(0.696)\end{array}$ & $\begin{array}{c}-0.967^{*} \\
(0.409)\end{array}$ & $\begin{array}{l}-0.513 \\
(0.313)\end{array}$ \\
\hline Rural (<2500 inhabitants) & $\begin{array}{l}-0.538 \\
(0.436)\end{array}$ & $\begin{array}{l}-0.278 \\
(0.240)\end{array}$ & $\begin{array}{l}-0.260 \\
(0.219)\end{array}$ \\
\hline$\%$ workers agriculture, 1990 & $\begin{array}{c}0.193 \\
(0.272)\end{array}$ & $\begin{array}{l}-0.007 \\
(0.162)\end{array}$ & $\begin{array}{c}0.200 \\
(0.137)\end{array}$ \\
\hline \% enrolled/1000 aged 12-14, 1991 & $\begin{array}{c}1.485^{* * * *} \\
(0.388)\end{array}$ & $\begin{array}{c}0.663^{* *} \\
(0.231)\end{array}$ & $\begin{array}{c}0.822^{* * *} \\
(0.212)\end{array}$ \\
\hline Constant & $\begin{array}{c}6.265^{* * *} \\
(1.690)\end{array}$ & $\begin{array}{c}5.054^{* * *} \\
(0.946)\end{array}$ & $\begin{array}{l}1.211 \\
(0.849)\end{array}$ \\
\hline F-First Stage & 13.23 & 13.23 & 13.23 \\
\hline Hausman test p-value & 0.23 & 0.31 & 0.24 \\
\hline Observations & 33,913 & 33,913 & 33,913 \\
\hline
\end{tabular}

Notes: Clustered SE at state level in parentheses. ${ }^{* * *} \mathrm{p}<0.001,{ }^{* *} \mathrm{p}<0.01,{ }^{*} \mathrm{p}<0.05$. Regressions also include cohort and state of birth fixed effects. Very effective methods were those with failure rate of $10 \%$ or less and include the implant, intrauterine device, male vasectomy, female sterilization, the pill, injectables, the patch and the emergency pill. Less effective methods were those with failure rates ranging from $12 \%$ to $28 \%$ and include male condom, female condom, spermicide, fertility awareness based methods and withdrawal. 